\title{
A Collection of Homes to Represent the U.S. Housing Stock
}

\author{
Andrew Persily \\ Building and Fire Research Laboratory, NIST \\ Amy Musser \\ Vandemusser Design LLC
}

Dennis Leber Information Technology Laborator', NIST

Prepared for: U.S. Department of Housing and Urban Development Office of Healthy Homes and Lead Hazard Control Washington, DC

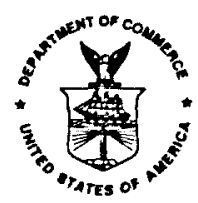

U.S. DEPARTMENT OF COMMERCE

Carlos M. Gutierrez, Secretan TECHNOLOGY ADMINISTRATION

Robert Cresanti, Undersecretany of Commerce for Teclmology NATIONAL INSTITUTE OF STANDARDS AND TECHNOLOGY William A. Jeffrey, Director 


\begin{abstract}
In order to allow nationwide or regional analyses of ventilation and indoor air quality issues in residential buildings, a collection or "suite" of homes has been defined to represent the housing stock of the United States. This collection of dwellings is based on two residential housing surveys, the U.S. Department of Energy Residential Energy Consumptions Survey (RECS) and the U.S. Census Bureau American Housing Survey (AHS), both of which are conducted periodically to characterize the U.S. housing stock. The RECS dataset includes about 6000 U.S. residences, and the AHS covers about 60,000 . Based on these datasets, just over 200 dwellings were defined that together represent $80 \%$ of the U.S. housing stock. These dwellings are grouped into four categories: detached, attached, manufactured homes and apartments. This paper describes the RECS and AHS datasets and how they were used to define this collection. Among the key characteristics addressed in defining these dwellings are age, floor area, number of floors, foundation type and existence of a garage. In addition, this report describes multizone representations of the dwellings that were created in the airflow model CONTAM and are now available for analyses of residential ventilation, indoor air quality and energy issues. The report documents the data sources used to develop the models, describes each model, and summarizes the testing of the models to establish their validity.
\end{abstract}

Keywords: database, housing, modeling, residential buildings, ventilation 


\section{Table of Contents}

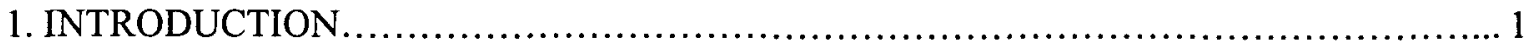

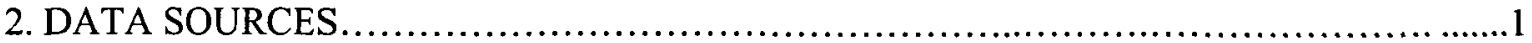

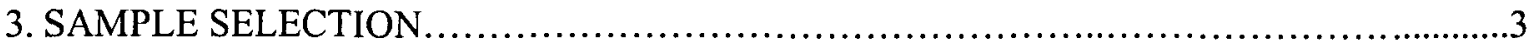

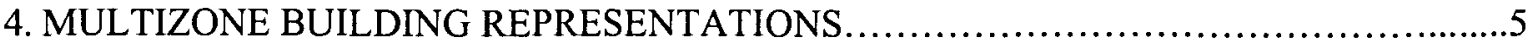

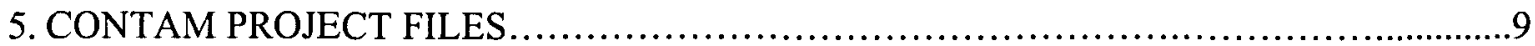

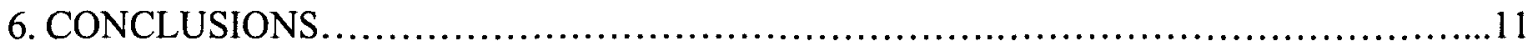

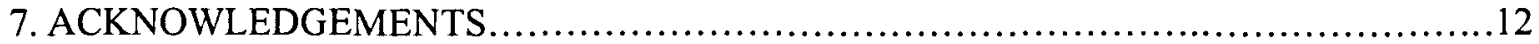

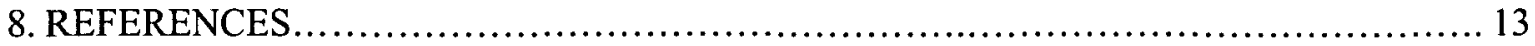
APPENDICES

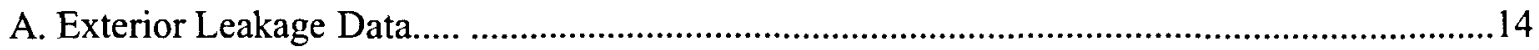

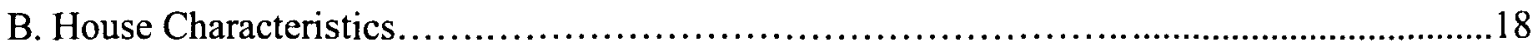

\section{BRAND NAME DISCLAIMER}

Certain trade names or company products are mentioned in the text to specify adequately the experimental procedure and equipment used. In no case does such identification imply recommendation or endorsement by the National Institute of Standards and Technology, nor does it imply that the equipment is the best available for the purpose. 


\section{INTRODUCTION}

Concerns about residential indoor air quality (IAQ) have led to the consideration of a number of interventions to improve indoor environmental conditions, including mechanical ventilation, air cleaning and moisture control strategies. The U.S. Department of Housing and Urban Development (HUD) established the Healthy Homes Initiative (HUD 1999a) to "protect children from housing conditions that are responsible for multiple diseases and injuries" by addressing building deficiencies that contribute to these multiple hazards rather than dealing with one problem at a time. Included among the program activities are the following: demonstrating the effectiveness of mold and moisture remediation practices; demonstrating and evaluating housing repairs directed towards preventing asthma, lead poisoning and other threats to health and safety; conducting public education programs targeted to low and medium income households; and, conducting research in support of the demonstration projects. Field studies and demonstration projects provide essential data on the potential IAQ impacts of such interventions in specific buildings. However, given the cost and complexity of field studies, simulation studies have also been used to investigate the impacts of various IAQ control measures (Emmerich et al. 2003 and 2005: Persily 1998; Emmerich and Persily 1996). This simulation work has also considered a relatively small number of buildings, making it difficult to draw general conclusions from the results. It is important to be able to assess the potential impact of IAQ controls on a larger scale, such as in a specific climate zone or even nationwide. Since determining such broad impacts through field testing would require an extensive and costly effort, modeling appears to be a more realistic option for drawing the types of conclusions on which policy decisions could be based. In order to obtain more reliable conclusions of a general nature and to support risk assessments, such modeling analysis needs to be performed on a set of buildings that is representative of the residential building stock. To this end, the National Institute of Standards and Technology (NIST) has undertaken an effort to define a representative collection of residential buildings based on a statistical analysis of the United States (US) housing stock. This paper describes the process by which these buildings were defined and their representation in the airflow and indoor air quality analysis program CONTAM (Walton and Dols 2005). Note that throughout this report the term "home" is used to describe individual housing units or dwellings, including apartment units within larger apartment buildings.

\section{DATA SOURCES}

In developing this collection of residential buildings, statistical analyses were performed on two residential building databases, the US Census Bureau's American Housing Survey (AHS) and the US Department of Energy's (DOE) Residential Energy Consumption Survey (RECS). Every other year the Census Bureau collects data via surveys and interviews to develop a housing inventory for HUD. The 1999 American Housing Survey is based on a representative sample of approximately 56,000 homes selected using a sampling method based on classifying all the counties in the US (HUD 1999b). The AHS is used to measure specific changes in the housing inventory and assess progress towards the goal of providing sustainable living conditions to all Americans. After collection of the survey data, the Census Bureau compiles all the data into a publicly available database on the American Housing Survey website, www.census.gov/hhes/www/housing/ahs/ahs.html.

The US Department of Energy (DOE) Residential Energy Consumption Survey (RECS) is a collection of statistical information on housing units and their occupants in the United States, with emphasis on the consumption of and expenditures for energy (DOE 1999). The RECS survey is conducted by DOE roughly every three or four years and can be found at www.eia.doe.gov/emeu/recs/contents.html. The 1997 survey was used in this effort and 
incorporates data from approximately 5900 housing units.

\begin{tabular}{|c|c|c|c|}
\hline & & \multicolumn{2}{|c|}{ Percentage } \\
\hline VARIABLE & VARIABLE RANGES & AHS & RECS \\
\hline \multirow[t]{4}{*}{ Unit Type } & Single, detached & 72.4 & 62.9 \\
\hline & Single, attached & 5.8 & 9.8 \\
\hline & Apartment & 16.1 & 21.1 \\
\hline & Manufactured home & 5.7 & 6.2 \\
\hline \multirow[t]{4}{*}{ Region } & Northeast & 16.6 & 19.4 \\
\hline & Midwest & 26.0 & 23.7 \\
\hline & South & 34.2 & 35.4 \\
\hline & West & 23.0 & 21.5 \\
\hline \multirow[t]{2}{*}{ Forced-air distribution } & Yes & 63.2 & 53.4 \\
\hline & No & 36.8 & 46.6 \\
\hline \multirow[t]{4}{*}{ Floor area * } & $<93 \mathrm{~m}^{2}\left(1000 \mathrm{ft}^{2}\right)$ & 14.0 & 29.0 \\
\hline & $93 \mathrm{~m}^{2}$ to $186 \mathrm{~m}^{2}\left(1000 \mathrm{ft}^{2}\right.$ to $\left.1999 \mathrm{ft}^{2}\right)$ & 46.1 & 45.1 \\
\hline & $186 \mathrm{~m}^{2}$ to $279 \mathrm{~m}^{2}\left(2000 \mathrm{ft}^{2}\right.$ to $\left.2999 \mathrm{ft}^{2}\right)$ & 21.7 & 13.0 \\
\hline & $>279 \mathrm{~m}^{2}\left(3000 \mathrm{ft}^{2}\right)$ & 10.7 & 4.0 \\
\hline \multirow[t]{6}{*}{ Occupants per household } & $\frac{1}{1}$ & 24.3 & 25.2 \\
\hline & 2 & 33.9 & 32.5 \\
\hline & $3-4$ & 31.6 & 32.2 \\
\hline & $5-6$ & 8.9 & $10.1(\geq 5)$ \\
\hline & $7-10$ & 1.2 & -- \\
\hline & $>10$ & 0.1 & $\overline{--}$ \\
\hline \multirow[t]{2}{*}{ Central air conditioning } & Yes & 52.0 & 42.1 \\
\hline & No & 48.0 & 57.9 \\
\hline \multirow[t]{7}{*}{ Year built } & $<1940$ & 17.3 & 19.9 \\
\hline & 1940-1949 & 7.4 & 9.3 \\
\hline & \begin{tabular}{|l}
$1950-1959$ \\
\end{tabular} & 13.1 & 13.1 \\
\hline & $1960-1969$ & 14.4 & 14.9 \\
\hline & $1970-1979$ & 19.8 & 13.2 \\
\hline & $1980-1989$ & 6.4 & 6.2 \\
\hline & $>1990$ & 21.6 & 23.4 \\
\hline \multirow[t]{2}{*}{ Garage or carport ** } & Yes & 56.4 & 53.7 \\
\hline & No & 43.5 & 25.2 \\
\hline \multirow[t]{3}{*}{ Foundations type ${ }^{* \star *}$} & Basement & 44.6 & 32.7 \\
\hline & Crawl space & 25.8 & 22.2 \\
\hline & Slab & 28.7 & 22.6 \\
\hline \multirow[t]{3}{*}{ Number of stories *** } & 1 & 35.1 & 55.8 \\
\hline & 2 & 35.1 & 39.8 \\
\hline & $\geq 3$ & 29.6 & 3.1 \\
\hline
\end{tabular}

* Does not include apartment units or single, attached units.

** Does not include apartment units.

*** RECS does not include apartment units, and both do not include manufactured homes.

Table 1 Summary of data from AHS and RECS

Given that the electronic format of the RECS database is easier to access and manipulate than the AHS database, the RECS data were used in the statistical analysis to define the representative suite of homes. However, the two surveys were compared to support the use of the AHS alone. The results of that comparison are shown in Table 1. Note that the two surveys differ in how they summarize the results for selected variables. For example floor area values in the AHS database 
do not include apartments or attached homes. Therefore, to better compare the two datasets, some of the variables in Table 1 do not include all housing types as noted. Note also that for some of the variables, the total percentages do not add up to $100 \%$ due to missing data.

\section{SAMPLE SELECTION}

The representative collection of homes was determined using a sampling scheme in which, for each of the four building types, a number of relevant building characteristics, or factors, in Table 1 were considered over a discrete number of "levels". For example, housing unit floor area is a factor and different ranges of floor area constitute the levels. The factors and factor levels considered for each building type are listed in Table 2. For each building type, each factor level was crossed with all other factor levels resulting in a factorial layout of cells defining the "population" for each housing type. In other words, each cell is defined by a single level of each factor, for example a cell of detached homes is defined by whether or not it has a forced-air system, a floor area level, the year built, existence of a garage, foundation type and number of stories. The number of cells by building type are as follows: Single, Detached and Single, Attached - 432; Apartment Units - 400; and, Manufactured Homes - 16. The RECS database assigns a "weight" for each housing unit or cell that defines how many units it represents nationwide. These weights were aggregated across building characteristics to represent each housing unit, or cell, in the overall population of dwellings considered in this effort. The first step in the sampling process was, for each building type (e.g., single family), to sort the cells in descending order based on the cell's weight. Figure 1 shows the percentage of homes covered for each of the four housing types as a function of the number of cells included. Note that the percent coverage increases very quickly for the manufactured homes due to the smaller amount of variation among these buildings. For all housing types, increasing the number of cells reaches a point where increasing the sample size does not lead to a significant increase in coverage.

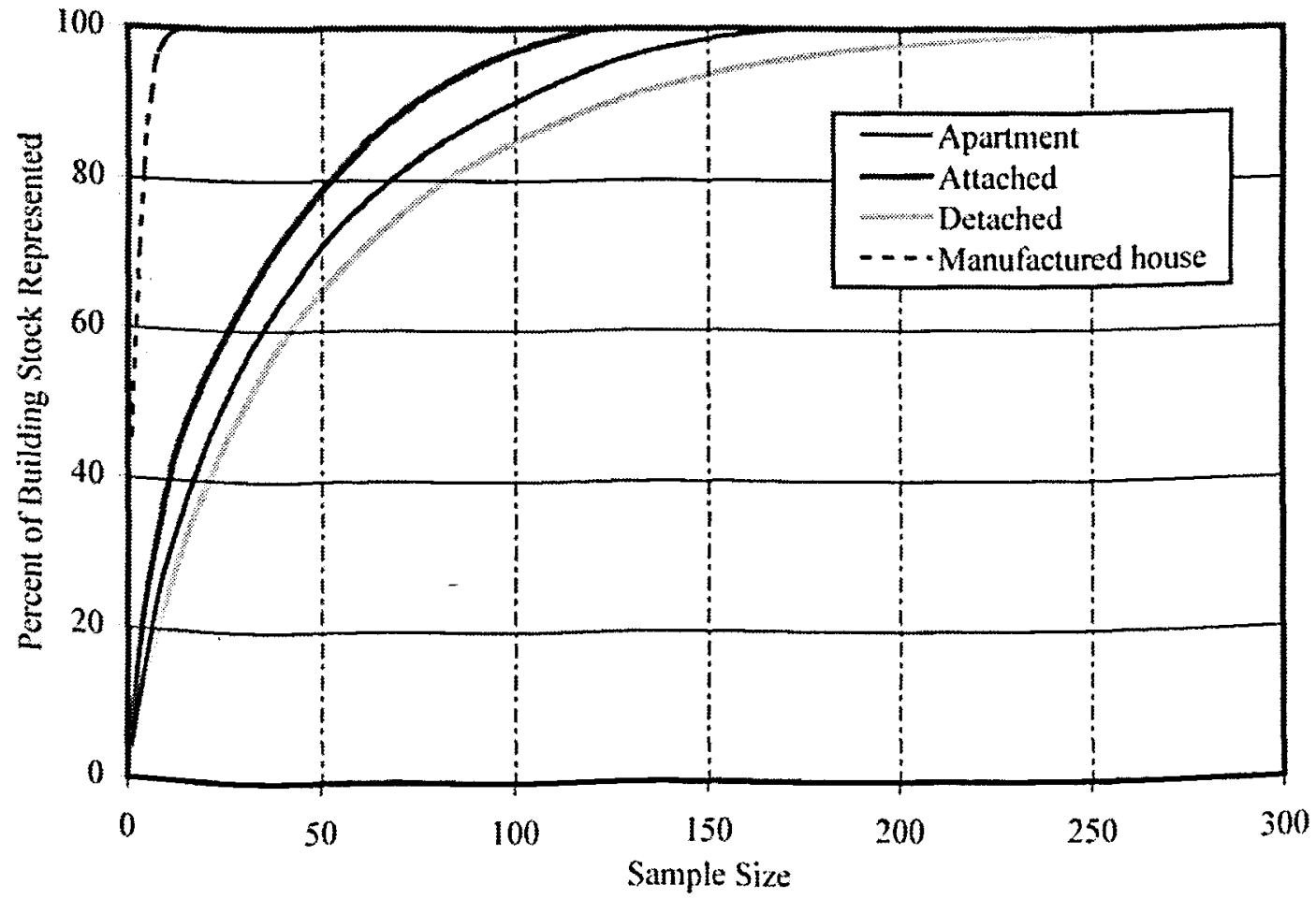

Figure 1: Percentage coverage as a function of sample size 


\begin{tabular}{|c|c|}
\hline VARIABLE & $\begin{array}{c}\text { VARIABLE RANGE } \\
\text { OR LEVEL }\end{array}$ \\
\hline \multicolumn{2}{|c|}{ SINGLE FAMILY (attached and detached) } \\
\hline \multirow[t]{2}{*}{ Forced-air distribution } & Yes \\
\hline & No \\
\hline \multirow[t]{3}{*}{ Floor area, $\mathrm{m}^{2}\left(\mathrm{ft}^{2}\right)$} & $<149(1600)$ \\
\hline & 149 to 223 (1600 to 2399$)$ \\
\hline & $>223(2400)$ \\
\hline \multirow[t]{4}{*}{ Year built } & $<1940$ \\
\hline & $1940-1969$ \\
\hline & $1970-1989$ \\
\hline & $1990-1997$ \\
\hline \multirow[t]{2}{*}{ Garage or carport } & Yes \\
\hline & No \\
\hline \multirow[t]{3}{*}{ Foundations type } & Basement \\
\hline & Crawl space \\
\hline & Slab \\
\hline \multirow{3}{*}{\begin{tabular}{|l} 
Number of stories \\
\end{tabular}} & 1 \\
\hline & 2 \\
\hline & $\geq 3$ \\
\hline \multicolumn{2}{|l|}{ APARTMENTS } \\
\hline \multirow[t]{5}{*}{ \# of units in building } & $2-4$ \\
\hline & $5-9$ \\
\hline & $10-19$ \\
\hline & $20-39$ \\
\hline & $>40$ \\
\hline \multirow[t]{2}{*}{ Floor area, $\mathrm{m}^{2}\left(\mathrm{ft}^{2}\right)$} & $<93(1000)$ \\
\hline & $>93(1000)$ \\
\hline \multirow[t]{4}{*}{ Year built } & $<1940$ \\
\hline & $1940-1969$ \\
\hline & $1970-1989$ \\
\hline & $>1990$ \\
\hline \multirow[t]{2}{*}{ Central heating system } & Yes \\
\hline & No \\
\hline \multicolumn{2}{|c|}{ MANUFACTURED HOMES } \\
\hline \multirow[t]{2}{*}{ Floor area, $m^{2}\left(f^{2}\right)$} & $<149(1600)$ \\
\hline & $>149(1600)$ \\
\hline \multirow[t]{4}{*}{ Year built } & $<1940$ \\
\hline & $1940-1969$ \\
\hline & $1970-1989$ \\
\hline & $>1990$ \\
\hline \multirow[t]{2}{*}{ Central forced-air system } & Yes \\
\hline & No \\
\hline
\end{tabular}

Table 2 Cells for each housing type

The next step in the process was to select the cells, again for each of the four housing types, which encompass $80 \%$ of the total number of units for that type. This approach led to unequal numbers of homes of each type, but comparable percentages of national coverage. Table 3 shows 
the number of homes and the percent of the total represented for $80 \%$ representation. Again, each home in the sample is defined by particular values of the variable levels in Table 2.

\begin{tabular}{|l|c|c|}
\hline Type of Housing & Sample Size & \% Represented \\
\hline Single, detached & 83 & 80.2 \\
\hline Single, attached & 53 & 80.2 \\
\hline Apartments & 69 & 80.4 \\
\hline Manufactured homes & 4 & 80.4 \\
\hline Total & 209 & 80.2 \\
\hline
\end{tabular}

Table 3 Summary of selected housing

\section{MULTIZONE BUILDING REPRESENTATIONS}

Once the 209 homes or dwellings were defined, floor plans were developed for subsequent entry into a CONTAM model of each house. These floor plans were based on the following variables from the AHS and RECS surveys: housing type, number of stories, heated floor area, year built, foundation type, garage, type of heating equipment, number of bedrooms, number of bathrooms, and number of other rooms. For apartment buildings, the total number of units in each building was also considered. The discussion below explains how each of these variables was considered in developing the multizone representation.

Type of Household: The four household types are detached, attached, apartment buildings, and manufactured homes. Detached and manufactured homes are modeled as free standing structures. Each attached home is modeled as a single townhouse with no leakage paths in the sidewalls between units. This arrangement is consistent with a center unit that has no net airflow or contaminant gain or loss from the adjacent unit. While having no leakage between adjacent units is not necessarily a good assumption in all cases, it is a practical necessity given the lack of data describing the airtightness of these walls and in order to keep the models manageable. Apartment buildings are modeled as entire buildings made up of identical apartment units, with leakage between units included.

Number of Stories: Attached and detached homes are listed in the surveys as one story, two or more stories, or "other". Homes in the "other" category are most commonly split level, and are modeled as such. To model a split-level home, it is necessary to include in the CONTAM model an extra level that is one-half story high. Each room is then modeled at its full height through the use of phantom zones, a CONTAM feature that allows a zone to extend through multiple building levels. Apartment buildings are divided into five height categories: 1, 2, 3-5, 6-15 and $16+$. One and two story buildings are modeled as such. The 3-5 story category is modeled as a four-story building, except for one case where a building with 6 units is modeled as three stories with two units on each floor. The 6-15 story category is modeled at a ten-story building, except in the case of one building with only 6 units, which was modeled as a 6-story building. The 16story building is modeled as 20 stories. All floors of multistory apartment buildings are modeled as identical, except for minor differences related to entrances on the first floors. All apartment buildings with four or more stories are modeled with elevators, except for the 6-story building with only one unit per floor.

Heated Floor Area: In all of the models, the heated floor area corresponds to the above ground portion of the home. For apartment buildings, the heated floor area given is per unit, and a 
reasonable amount of additional space for corridors, lobbies, etc. is added to the whole building model. The set of 209 dwellings are divided into either two or three floor area categories, depending on the type of dwelling. These categories are consolidated from a larger number of categories (usually four to five) in the original RECS data. The floor area used in the models of each floor plan is calculated as the weighted average of each included RECS category. RECS categories are represented by the mean of the upper and lower bound for each category. RECS categories with only an upper or lower bound (for example, greater than $149 \mathrm{~m}^{2}\left(1,600 \mathrm{ft}^{2}\right)$ ) are represented by values $10 \%$ greater than or $10 \%$ less than the upper or lower bound given. The following example demonstrates this calculation, and the results for all of the housing types are summarized in Table 4.

For example, the manufactured houses in the collection are all in the floor area category of "less than $148.5 \mathrm{~m}^{2}\left(1,599 \mathrm{ft}^{2}\right)$." This floor area category has been consolidated from three RECS categories: $92.9 \mathrm{~m}^{2}$ to $145.8 \mathrm{~m}^{2}\left(1,000 \mathrm{ft}^{2}\right.$ to $\left.1,599 \mathrm{ft}^{2}\right)$, which accounts for $35 \%$ of houses in the group; $55.7 \mathrm{~m}^{2}$ to $92.8 \mathrm{~m}^{2}\left(600 \mathrm{ft}^{2}\right.$ to $\left.999 \mathrm{ft}^{2}\right)$, which accounts for $48 \%$ of houses in the group; and less than $55.7 \mathrm{~m}^{2}\left(600 \mathrm{ft}^{2}\right)$, which accounts for $17 \%$ of houses. Representing the three RECS categories by $120.1 \mathrm{~m}^{2}, 74.3 \mathrm{~m}^{2}$ and $50.2 \mathrm{~m}^{2}\left(1,300 \mathrm{ft}^{2}, 800 \mathrm{ft}^{2}\right.$ and $\left.540 \mathrm{ft}^{2}\right)$, respectively, yields a weighted average of $86.3 \mathrm{~m}^{2}\left(929 \mathrm{ft}^{2}\right)$ for the "less than $148.5 \mathrm{~m}^{2}\left(1,599 \mathrm{ft}^{2}\right)$ " category.

\begin{tabular}{|l|c|c|}
\hline \multicolumn{1}{|c|}{ Housing type } & $\begin{array}{c}\text { Floor area category } \\
\mathbf{m}^{\mathbf{2}}\left(\mathbf{f t}^{\mathbf{2}}\right)\end{array}$ & $\begin{array}{c}\text { Floor area in } \\
\text { model } \mathbf{~}^{\mathbf{2}}\left(\mathbf{f t}^{\mathbf{2}}\right)\end{array}$ \\
\hline \multirow{4}{*}{ Detached } & Less than $148.5(1,599)$ & $107.0(1152)$ \\
\hline \multirow{3}{*}{ Attached } & 148.6 to $222.9(1,600$ to 2,399$)$ & $180.4(1942)$ \\
\cline { 2 - 3 } & $223.0(2,400)$ or more & $275.5(2966)$ \\
\hline Manufactured & Less than $148.5(1,599)$ & $96.3(1037)$ \\
\hline \multirow{2}{*}{ Apartments, 2-4 units } & 148.6 to $222.9(1,600$ to 2,399$)$ & $175.6(1891)$ \\
\cline { 2 - 3 } & $223.0(2,400)$ or more & $261.3(2813)$ \\
\hline \multirow{2}{*}{ Apartments, 5 units or more } & Less than $148.5(1,599)$ & $86.3(929)$ \\
\cline { 2 - 3 } & Less than $92.8(999)$ & $65.4(704)$ \\
\cline { 2 - 3 } & $92.9(1000)$ or more & $142.1(1530)$ \\
\hline
\end{tabular}

Table 4 Weighted average floor area by housing type and category.

Year Built: The year of construction is used to assign the exterior wall leakage based on data from two studies of airtightness on single-family homes (Sherman and Dickeroff 1998; Chan, et al. 2003 and 2005). Exterior wall leakage, in terms of the normalized leakage area, is defined as a function of both year built and house floor area as described in Appendix A and presented in Table 5. The normalized leakage (NL) values from this table are converted to an effective leakage area (ELA) for use in the house models using the following equation that defines NL (ASHRAE 2005):

$$
N L=1000 \frac{E L A}{A_{f}}\left(\frac{H}{2.5}\right)^{0.3}
$$

where, $A_{f}$ is the floor area in $\mathrm{m}^{2}$ and $H$ is the building height in $\mathrm{m}$. 


\begin{tabular}{|c|c|c|}
\hline & \multicolumn{2}{|c|}{ Normalized leakage area (dimensionless) } \\
\hline Year built & $\begin{array}{c}\text { Floor area less than } \\
148.6 \mathrm{~m}^{2}\left(1600 \mathrm{ft}^{2}\right)\end{array}$ & $\begin{array}{c}\text { Floor area greater than } \\
148.6 \mathrm{~m}^{2}\left(1600 \mathrm{ft}^{2}\right)\end{array}$ \\
\hline Before 1940 & 1.29 & 0.58 \\
\hline $1940-1969$ & 1.03 & 0.49 \\
\hline 1970-1989 & 0.65 & 0.36 \\
\hline 1990 and newer & 0.31 & 0.24 \\
\hline
\end{tabular}

Table 5. Normalized leakage by construction year and floor area

Foundation Type: Detached and attached homes have three foundation type options in the RECS database: concrete slab, crawl space and basement. All manufactured homes are modeled with crawlspaces, and all apartment buildings with concrete slabs. The concrete slab option is modeled with no leakage paths to the outdoors through the floor. The crawl space option is

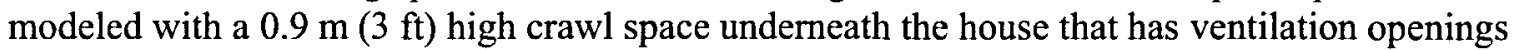
to the outdoors. Four total openings are used for each house, located at the corners, and having openings to the outdoors totaling $1 / 150$ of the floor area of the crawlspace, which is a rule of thumb that has been used over many years. However, more recent guidance has questioned the desirability of any crawl space venting at all if a moisture-retardant ground cover is installed (ASHRAE 2003). The per area leakage between the crawlspace and the house is the same as the exterior wall leakage for the house. Basements are modeled as $2.4 \mathrm{~m}(8 \mathrm{ft})$ high spaces with the same footprint as the house (except for the case of an attached home with a garage and basement as described below). Unfinished basements are modeled as unconditioned space and are closed off from the upper part of the house with a closed door. If unfinished, they are assumed to have

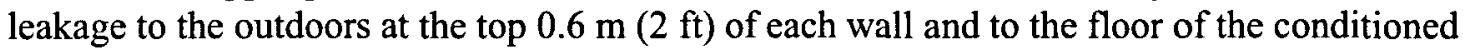
house above. This leakage is the same as the exterior wall leakage for the exterior walls of the house. Finished basements are modeled with an open staircase to the upper floors, and the leakage per area of the basement-house interface is the same as the interior walls. Finished

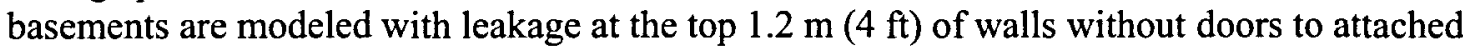
garages and with leakage on the entire $2.4 \mathrm{~m}(8 \mathrm{ft})$ of walls that have doors to a garage.

Garage: Some of the detached and attached homes have attached garages, which are considered as unconditioned spaces. Detached homes are modeled with a two car garage, either $45.0 \mathrm{~m}^{2}$ or $53.5 \mathrm{~m}^{2}\left(484 \mathrm{ft}^{2}\right.$ or $\left.576 \mathrm{ft}^{2}\right)$ in size depending on the floor plan, attached to the first story of the home. Attached homes are modeled with one or two car garages, which are $53.5 \mathrm{~m}^{2}, 59.1 \mathrm{~m}^{2}$ or $35.7 \mathrm{~m}^{2}\left(576 \mathrm{ft}^{2}, 528 \mathrm{ft}^{2}\right.$ or $\left.384 \mathrm{ft}^{2}\right)$ in size depending on floor plan, on the lowest story of the home. Where an attached home is specified with an attached garage and basement, the garage and basement share the lowest level of the home. Garage (exterior) walls are modeled with leakage values two times that of the exterior walls. This is based on the findings of a study of the leakage of attached garages relative to houses (Emmerich et al. 2003).

Type of Heating Equipment: Homes in the database have two heating system options: "Central system," which means forced-air distribution, and "other". Systems in the "other" category are assumed not to include forced air fans or outdoor air ventilation, and are thus not included in the airflow models. Homes with central systems are modeled with a simple air handling system that has balanced supply and return airflows of $6.1 \mathrm{~L} / \mathrm{s}^{\bullet} \mathrm{m}^{2}\left(1.2 \mathrm{cfm} / \mathrm{ft}^{2}\right)$ of floor area (ASHRAE 1989). No outdoor air ventilation is introduced by the systems for detached, attached or 
manufactured houses. In some cases, the system model includes duct leakage. Homes with unconditioned basements are modeled with return duct leakage from the basement equal to $10 \%$ of the total system flow. If the basement is conditioned, no supply or return leakage is modeled. Houses with crawlspaces and slab-on-grade construction are modeled with a supply leak (equal to $10 \%$ of the system flow) in the attic. If these houses also have a garage, an equivalent return leak is located in the garage; otherwise, no return leak is modeled.

Apartment buildings with "central systems" are also modeled with simple air handling systems that supply the apartments with balanced supply and return airflows of $6.1 \mathrm{~L} / \mathrm{s}^{\bullet} \mathrm{m}^{2}\left(1.2 \mathrm{cfm} / \mathrm{ft}^{2}\right)$ of floor area and no outdoor air or duct leakage. If the apartment building has fewer than 32 units, each unit has its own air handling system. Buildings that have 32 or more units are modeled with all units on each floor sharing the same aif handling system. All apartment buildings are also modeled with kitchen and bathroom exhaust fans that remove $47 \mathrm{~L} / \mathrm{s}$ (100 cfm) per kitchen and $22 \mathrm{~L} / \mathrm{s}(50 \mathrm{cfm})$ per bathroom. These exhausts are modeled using single simple air handling units with only returns; these returns are scheduled as "off' in the model, but can be scheduled to operate if desired. Apartments with corridors have $100 \%$ outdoor air systems that supply $21 \mathrm{~L} / \mathrm{s}(45 \mathrm{cfm})$ per unit opening onto each corridor. This airflow is intended to maintain pressurization of the building and to provide makeup air for unit exhaust fans. The duct system volumes are calculated as follows: supply ducts are assumed to be $20 \mathrm{~cm}(8 \mathrm{in})$ in diameter and twice the long dimension of the building or apartment unit, and return ducts are also assumed to be $20 \mathrm{~cm}(8 \mathrm{in})$ in diameter but half the long dimension of the building or unit.

Number of Rooms: The RECS data set includes information on numbers of rooms in each home and apartment. For each of the 209 houses, the percentage of dwellings with each number of the following room types was determined: bedrooms, bathrooms, half baths, and others. From this data, a weighted average of the number of each room type reported for each of the 209 dwellings was calculated, which was then rounded to the nearest whole number and used to build the models. The tables in Appendix B summarize the number of rooms and other key modeling variables for the 209 dwellings. In translating the number of rooms to specific floor plans, several conventions were used. When only one bathroom is present, it is located centrally with access from a hallway. Half baths are located with access from the main living space. Additional bathrooms are modeled as master bathrooms and located in proximity to the largest bedroom. The number of other rooms in the models varies from one to five. The naming convention for "other" rooms is as follows: the first other room is labeled as the "kitchen", the second as the "living room", the third as the "dining room", the fourth as the "den" and the fifth as "storage."

Number of Units: Buildings in the apartment category are assigned a number of units. There are five categories for this variable: $2-4,5-9,10-19,20-39$, and $40+$. The $40+$ units category is modeled by a building with 20 units per floor. The $20-39$ category is modeled with 32 units; the 10-19 category is modeled with 16 units; the 5-9 category is modeled with 6 units; and the 2-4 category is modeled with 4 units. These values were selected to provide conveniently divisible numbers of units so that most buildings could be modeled with identical floors. In a few cases, this was not possible, for example, a four story building with six total units. In that case, the building was modeled with two identical lower floors with two units each, and two identical upper floors with one unit each.

Finished Basements: Survey data report that approximately $75 \%$ of houses have some finished basement area that is included in the total floor area reported by the survey. Floor plans that include finished basements were selected from among the floor plans that include basements, so 
that their percentage (when weighted according to the survey) was approximately $75 \%$. Floor plans that include finished basements have the entire basement finished, except in the case of attached housing with garages. In this case, the finished basement and the garage share the lowest level of the home.

Inclusion of doors in the model: The effect of exterior doors on exterior wall leakage is included in the exterior wall leakage values cited above. However, one front exterior door is also included in each model, each with an effective leakage area of $12 \mathrm{~cm}^{2}\left(1.9 \mathrm{in}^{2}\right)$. Basement doors are also included and modeled as open if the basement is finished and closed with a leakage of $21 \mathrm{~cm}^{2}\left(3.3 \mathrm{in}^{2}\right)$ each if the basement is unfinished. If a garage is present, the door connecting the garage and house is modeled as closed with a leakage of $21 \mathrm{~cm}^{2}\left(3.3 \mathrm{in}^{2}\right)$ each. These leakage values are the "best estimate" values from ASHRAE (2001) for single doors weatherstripped and not weatherstripped, respectively. Apartment buildings that include elevators have elevator doors modeled with a leakage of $226 \mathrm{~cm}^{2}\left(35 \mathrm{in}^{2}\right)$ each. This is the average elevator door leakage from a study of seven buildings (Tamura and Shaw 1976).

Attics: Unconditioned attics are included in the attached, detached and manufactured houses. Attics are also included in the models of one and two story apartment buildings with four units per building. The attic models have vents to ambient with a free area equal to $1 / 150$ of the floor area of the attic. The temperature of these spaces is the same as the indoor temperature, but can be changed if desired.

Conditioned and unconditioned spaces: In the project files, attics, unconditioned basements, crawlspaces and garages are considered unconditioned spaces within CONTAM. This designation means that when CONTAM calculates a building air change rate, these spaces are not included in that calculation but are considered to be part of the ambient zone. In practice, this means that only the conditioned spaces are included in the building volume and only airflows into these spaces from outdoors or from non-conditioned spaces are included in the air change rate calculation. If desired, such spaces can be designated as conditioned within CONTAM and thereby included in the air change rate calculation within CONTAM. Apartment building corridors, stairs and elevators are considered part of the building's conditioned space.

\section{CONTAM PROJECT FILES}

CONTAM project files describing the 209 dwellings discussed above have been created following the conventions described in the previous section. Appendix B summarizes the 209 dwellings and identifies the corresponding project file name and associated floor plan. The project files and the floor plans are available for download at the CONTAM website www.bfrl.nist.gov/IAQanalysis under Case Studies.

\section{Project File Testing}

Four different tests were performed to verify the accuracy of the CONTAM project files. These include tests of wind pressure profiles, air handling unit flows, air change rates and building pressurization. Detailed results of these tests are contained in an Excel file titled "Suite of homes project file tests.xls," which is also available at the website noted above.

The wind profile test checks that all exterior leakage paths are associated with a wind pressure profile and that the wall azimuth angle of each path is correct. The test is performed within the CONTAM interface using the "View... wind pressure" command. 
Air handling unit flows were tested by running a steady state simulation for each project file and verifying the total outdoor air, return air and exhaust airflow rates for each air handling unit. In the detached, attached and manufactured homes, the outdoor air and exhaust airflow rates should be zero and the return airflow rate should be $6.1 \mathrm{~L} / \mathrm{s}^{\bullet} \mathrm{m}^{2}\left(1.2 \mathrm{cfm} / \mathrm{ft}^{2}\right)$ of floor area, These airflow rate tests are considered to be passed if the calculated airflows are within $1 \%$ of the target value. In apartment buildings, it was also necessary to test the air handling units associated with corridors and exhaust fans. Exhaust fan flows are correct if the outdoor air, return air and exhaust air are all zero, since these are scheduled off. Corridor airflows are correct if return and exhaust airflow rates are zero, and the outdoor airflow rate equals $21 \mathrm{~L} / \mathrm{s}(45 \mathrm{cfm})$ per unit.

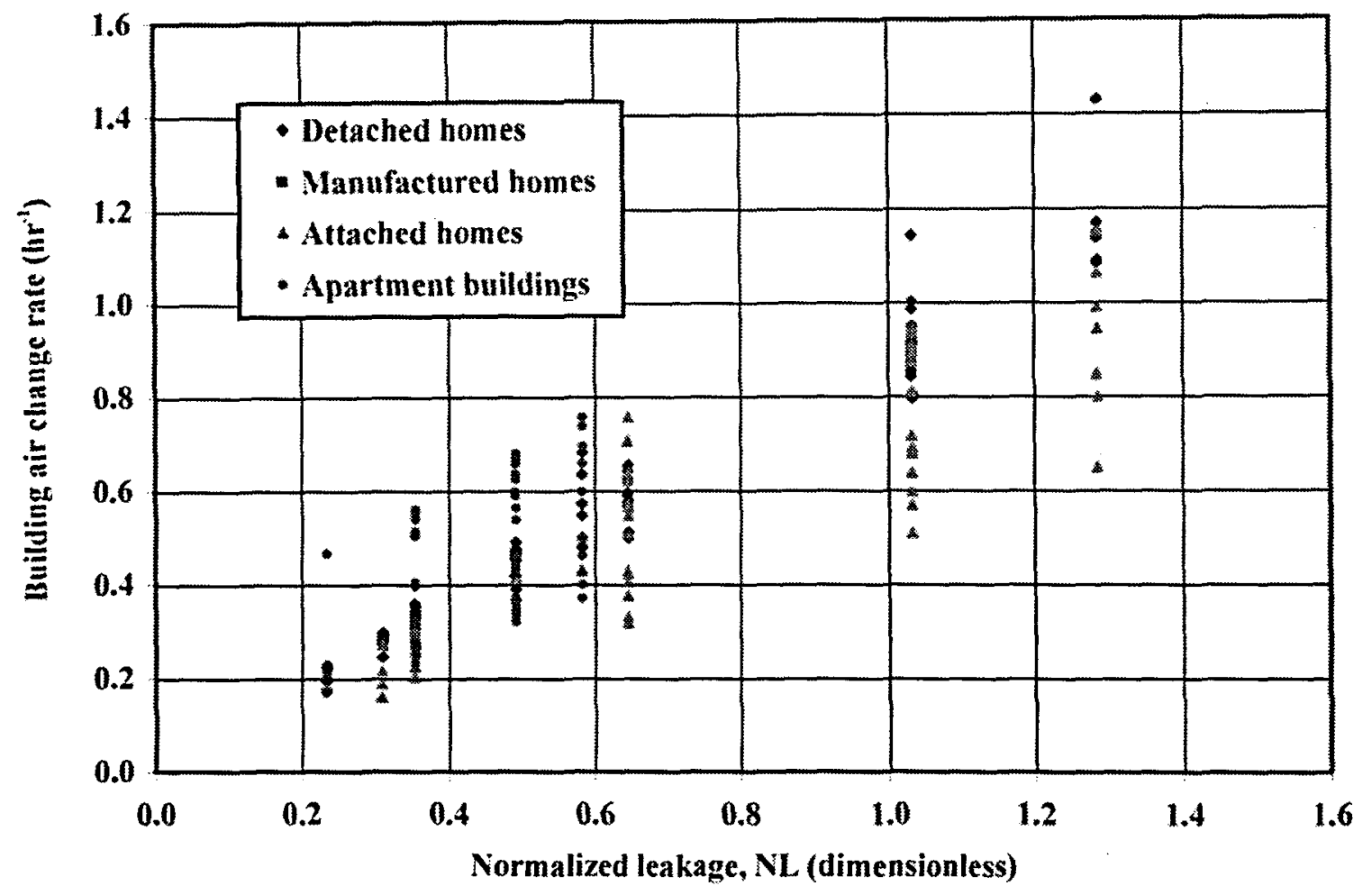

Figure 2 Building air change rate test results.

Air change rate tests were conducted without the air handling systems operating (except those of the apartment building corridor systems). These tests involved running steady-state CONTAM simulations to calculate the building air change rates with the outdoor temperature $20^{\circ} \mathrm{C}\left(36^{\circ} \mathrm{F}\right)$ lower than the indoor temperature and an outdoor wind speed of $5 \mathrm{~m} / \mathrm{s}(11 \mathrm{mph})$. Attics, unconditioned basements, crawlspaces and garages were not included in the building volume for these calculation. Apartment building corridors, stairs and elevators were considered part of the building's conditioned volume. Figure 2 presents the calculated building air change rates as a function of normalized leakage for the 209 dwellings under the defined test conditions. These results follow the expected trend based on normalized leakage and house design. Note that the apartment buildings divide into two general groups: one with no corridors and lower air change rates, and another with corridors and higher air change rates due to corridor ventilation. Table 3 summarizes the minimum, maximum, and average air change rate by type of dwelling type. 


\begin{tabular}{|l|c|c|c|}
\hline House type & Maximum & Minimum & Average \\
\hline Detached & 1.43 & 0.18 & 0.59 \\
\hline Attached & 1.15 & 0.16 & 0.60 \\
\hline Manufactured & 0.89 & 0.28 & 0.57 \\
\hline Apartment & 0.76 & 0.17 & 0.46 \\
\hline
\end{tabular}

Table 6. Summary of building air change rate test results (in units of $\mathrm{h}^{-1}$ )

Simulated building pressurization tests were also performed to verify the exterior leakage of each house. This test is done in practice by pressurizing the conditioned volume of each building with an imposed airflow, and then measuring the airflow rate and pressure difference at this pressurized condition. Using the surface area of each house, the ELA for the building is then calculated and compared with the input value, as described in ASHRAE (2005). This test serves to verify that all required exterior wall leakage paths are present, and have the correct ELA and surface area input. CONTAM has a simulation mode that mimics a pressurization test, which was used for these model tests. Due to the presence of exterior doors and attached garages, attics and other spaces in the models, the input and calculated ELA do not always match exactly. Models were deemed acceptable if the ELA determined through the CONTAM simulations was within $0.2 \mathrm{~cm}^{2} / \mathrm{m}^{2}\left(0.003 \mathrm{in}^{2} / \mathrm{ft}^{2}\right)$ of the input value.

\section{SUMMARY AND DISCUSSION}

This collection of homes has been developed to represent the U.S. residential building stock for use in residential ventilation and indoor air quality analysis. The development and availability of the corresponding CONTAM models of these buildings will enable nationwide analyses and risk assessments of residential ventilation and indoor air quality issues.

One followup activity that is currently in progress is to further characterize these 209 dwellings based on additional information contained in the RECS survey. To that end, a so-called "counting exercise" was performed in which the fractions of homes in the survey captured by each of the 209 dwellings was sorted by each of the following variables:

Number of household occupants

Number of occupants less than 1 year old, between 1 and 12 years old, greater than 65 years, and greater than 75 years

Part of public housing projects (yes or no)

Cooking fuel (3 options)

Census division (8 options)

Existence of a clothes dryer (yes or no)

Main home heating equipment (12 options) and heating fuel (6 options)

Use of stove as auxiliary heat (yes or no)

Main water heating fuel (4 options)

The results of this exercise will allow more detailed characterization of the 209 dwellings for use in future analyses of building ventilation, indoor air quality and exposure. For example, the information on distribution by census division is being used to generate a nationwide frequency distribution of ventilation rates. In this effort, nineteen U.S. cities have been identified to represent climatic variations within each census region, along with weighting factors that characterize the number of each dwelling type that exists in each city. Year-long CONTAM simulations will be run for each dwelling in each city to determine building ventilation rates for 
each hour of the year. These results will then be combined based on the house/city weighting factors to develop a national frequency distribution of ventilation rates. This distribution will be compared with other such ventilation rate distributions based on tracer gas measurements (Pandian et al. 1998), but which were not based on a representative group of homes, as well as a California-specific ventilation rate database (Wilson et al. 1996).

\section{ACKNOWLEDGEMENTS}

This work was sponsored under an Interagency Agreement with the U.S Department of Housing and Urban Development, Office of Healthy Homes and Lead Hazards Control. 


\section{REFERENCES}

ASHRAE 1989. ASHRAE Pocket Guide for Air Conditioning, Heating, Ventilation, Refrigeration. American Society of Heating Refrigerating and Air-Conditioning Engineers. Atlanta, GA.

ASHRAE. 2001. Handbook of Fundamentals. American Society of Heating Refrigerating and Air-Conditioning Engineers.

ASHRAE. 2003. Handbook of HVAC Applications, Chapter 43 Building Envelopes. American Society of Heating Refrigerating and Air-Conditioning Engineers.

ASHRAE. 2005. Handbook of Fundamentals. American Society of Heating Refrigerating and Air-Conditioning Engineers.

Chan W, Price P, Sohn M, Gadgil A. 2003. Analysis of U.S. Residential Air Leakage Database. LBNL 53367. Lawrence Berkeley National Laboratory.

DOE 1999. A Look at Residential Energy Consumption in 1997. DOE/EIA-0632(97). U.S. Department of Energy.

Emmerich SJ, Howard-Reed C, Gupta A. 2005. Modeling the IAQ Impact of HHI Interventions in Inner-City Housing. NISTIR 7212, National Institute of Standards and Technology.

Emmerich S, Gorfain J, Huang M, Howard-Reed C. 2003. Air and Pollutant Transport from Attached Garages to Residential Living Spaces. NISTIR 7072, National Institute of Standards and Technology.

Emmerich, SJ and AK Persily. 1996. Multizone Modeling of Three Residential Indoor Air Quality Control Options. NISTIR 5801, National Institute of Standards and Technology.

HUD. 1999a. The Healthy Homes Initiative: A Preliminary Plan. U.S. Department of Housing and Urban Development, Office of Lead Hazard Control.

HUD. 1999b. American Housing Survey for the United States. H150/99. U.S. Department of Housing and Urban Development, U.S. Department of Commerce.

Pandian MD, Behar JV, Ott WR, Wallace LA, Wilson AL, Colome SD, Koontz M. 1998. Correcting Errors in the Nationwide Data Base of Residential Air Exchange Rates. Journal of Exposure Analysis and Environmental Epidemiology. 8(4): 577-591.

Persily A, Leber D. 2003. A Suite of Homes Representing U.S. Housing Stock. Ventilation, Humidity Control and Energy, Proceedings of the 24th Air Infiltration and Ventilation Centre (AIVC) Conference and Building Environment and Thermal Envelope Council (BETEC) Conference, Washington, DC, pp. 15-20.

Persily AK. 1998. A Modeling Study of Ventilation, IAQ and Energy Impacts of Residential Mechanical Ventilation. NISTIR 6162, National Institute of Standards and Technology.

Sherman M, Dickeroff D. 1998. Air-tightness of U.S. Dwellings. ASHRAE Transactions, 104(2): 1359-1367.

Tamura G, Shaw J. 1976. Air Leakage Data for the Design of Elevator and Stair Shaft Pressurization Systems. ASHRAE Transactions. 82(2): 179-190.

Wilson AL, Colome SD, Tian Y, Becker EW, Baker PE, Behrens DW, Billick IH, Garrison CA. 1996. California Residential Air Exchange Rates and Residence Volumes. Journal of Exposure Analysis and Environmental Epidemiology. 6(3): 31 1-326. 


\section{APPENDIX A: Exterior Leakage Data}

Data for exterior envelope leakage as a function of building age were examined from two Lawrence Berkeley National Laboratory (LBNL) studies (Sherman and Dickeroff 1998, Chan et al., 2003 and 2005). The older report provides data for a sample of approximately 1500 houses. The newer analysis contains leakage data as a function of building age and floor area for approximately 3500 houses. However, the floor area and age categories used to present these tabular data are not exactly the same as the categories used to develop the collection of homes described in the body of this report.

Figure Al shows normalized leakage area plotted against year built from both LBNL reports. The Sherman and Dickeroff $(S+D)$ data are shown in the same age ranges used to define the collection of homes. The Chan data are shown in slightly different age ranges. In the figure, the data from the earlier Sherman and Dickeroff study track the normalized leakage from the smaller two size ranges in the Chan study fairly well. Also, the similarity of these data sets suggests that the data from the Chan study could reasonably be extrapolated down to a "year built" of 1940 . The larger three size ranges in the Chan study (those with floor areas above $139 \mathrm{~m}^{2}\left(1,500 \mathrm{ft}^{2}\right)$ have lower normalized leakage, but track one another fairly closely.

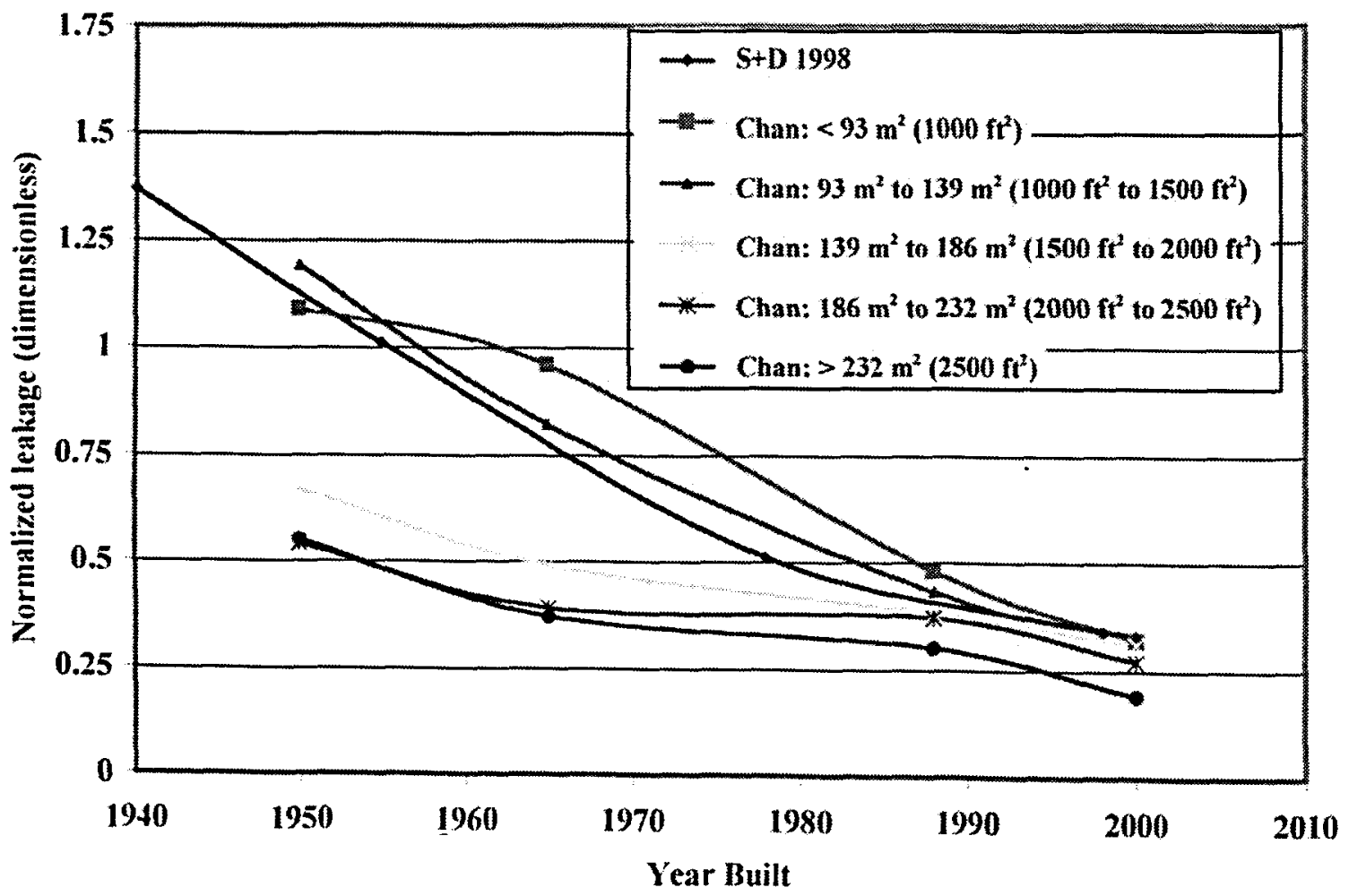

Figure A1 Normalized leakage vs. Year built (Sherman and Dickeroff 1998; Chan et al., 2003 and 2005)

For this project, data from Chan et al. were adapted to the age ranges used to define the model dwellings based on the trends noted above. The "before 1940" range was represented by houses built in 1940, "1990 and newer" was represented by the year 1998, and the other categories were represented by the midpoint of the category. For floor areas less than $148.5 \mathrm{~m}^{2}\left(1,599 \mathrm{ft}^{2}\right)$, the

two smaller Chan categories were averaged, and least squares regression analysis was used to 
obtain values for the ages needed. For floor areas greater than $148.6 \mathrm{~m}^{2}\left(1,600 \mathrm{ft}^{2}\right)$, the three larger Chan categories were averaged and regressed against year built. Figure A2 shows the normalized leakage vs. year built for the two aggregated Chan floor area groups and the values used to develop the suite of homes. Table A1 summarizes the values used for the suite of homes.

\begin{tabular}{|l|c|c|}
\hline & \multicolumn{2}{|c|}{ Normalized leakage area (dimensionless) } \\
\hline \multicolumn{1}{|c|}{ Year built } & $\begin{array}{c}\text { Floor area less than } \\
\mathbf{1 4 8 . 6} \mathbf{~ m}^{\mathbf{2}}\left(\mathbf{1 6 0 0} \mathbf{f t}^{\mathbf{2}}\right)\end{array}$ & $\begin{array}{c}\text { Floor area less than } \\
\left.\mathbf{1 4 8 . 6} \mathbf{~ m}^{2} \mathbf{( 1 6 0 0} \mathbf{f t}^{\mathbf{2}}\right)\end{array}$ \\
\hline Before 1940 & 1.29 & 0.58 \\
\hline $1940-1969$ & 1.03 & 0.49 \\
\hline $1970-1989$ & 0.65 & 0.36 \\
\hline 1990 and newer & 0.31 & 0.24 \\
\hline
\end{tabular}

Table A1. Normalized leakage by construction year and square footage

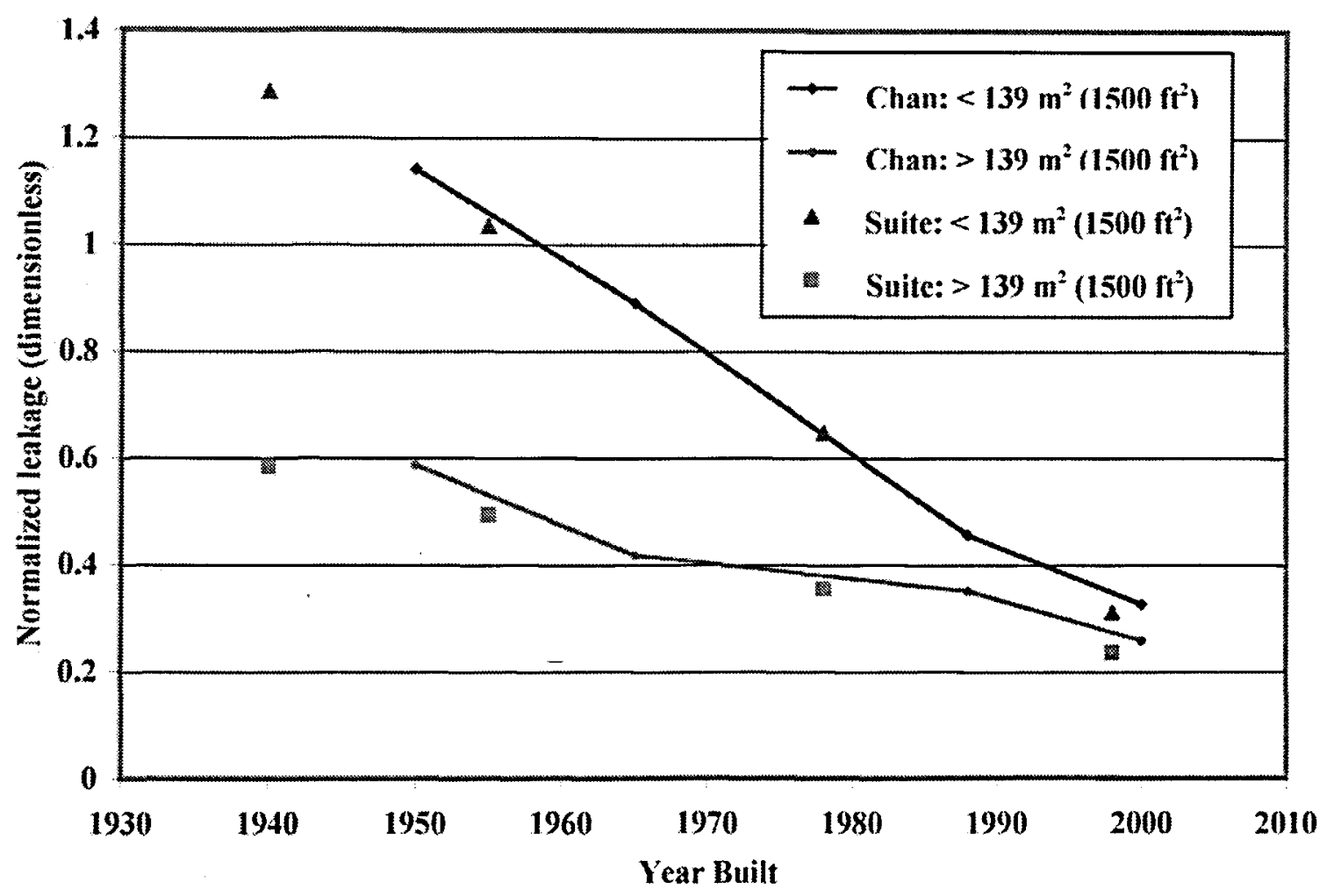

Figure A2. Normalized leakage vs. Year built (values used to develop the suite of homes)

The leakage of the exterior walls for the apartment buildings were determined from the leakage data for the houses in the collection with floor areas greater than $148.6 \mathrm{~m}^{2}\left(1600 \mathrm{ft}^{2}\right)$. While the appropriateness of these data for apartment buildings is questionable, there are no large scale studies that provide age-related leakage data for this type of building. The leakage areas used are, however, compared with the limited data from apartment buildings in the literature (CEE 2004).

Figures $\mathrm{A} 3$ and $\mathrm{A} 4$ show the ELA of the detached homes in the collection defined by this project and the apartment buildings in CEE (2004) plotted as a function of building square footage. These plots show that the ELA values for the two types of buildings have a similar range, though the larger apartment buildings are somewhat leakier than the largest houses. 


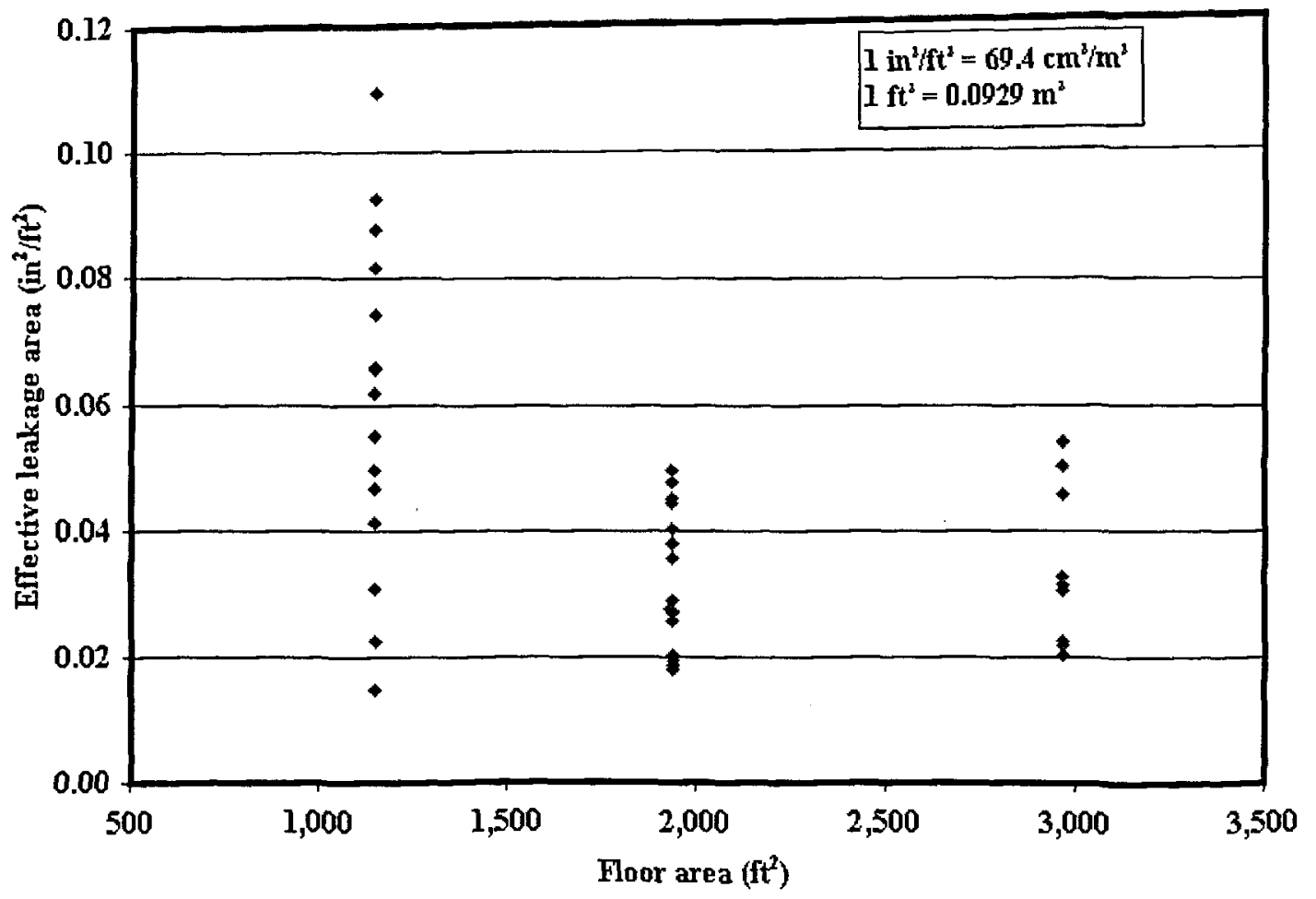

Figure A3 Detached home leakage

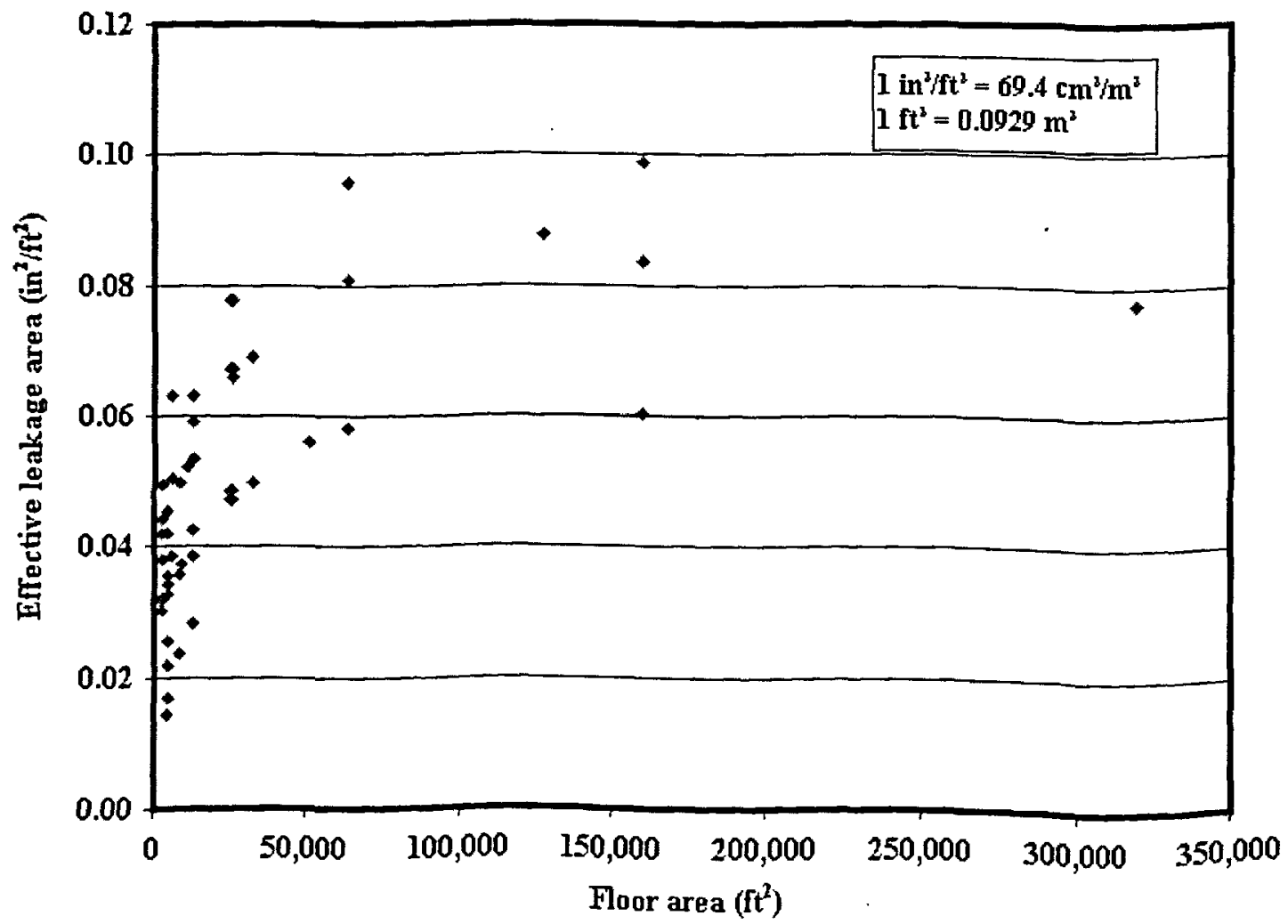

Figure A4 Apartment building leakage 
Measured airflow rates at a $50 \mathrm{~Pa}$ indoor-outdoor pressure difference have been published for individual apartment units located in buildings of known age and number of units (CEE 2004), which can be compared with the results of a CONTAM simulation of a pressurization test for the apartment building models defined in this project. Unfortunately, the size of the apartment unit, its location within the building, and the distribution between indoor and outdoor leakage were not documented in the CEE effort. Table A2 compares the airflow rate required to pressurize the building to a pressure of $50 \mathrm{~Pa}$ (designated as Q50) measured in that study with that simulated in a similar building from this set of dwellings. For these six cases, the suite of homes has a higher Q50 value in four cases and a lower value in two cases. The two larger buildings do have lower measured Q50 values, however, the exact size of those units is not known.

\begin{tabular}{|l|c|c|c|c|c|c|}
\hline \multicolumn{5}{|c|}{ Suite of homes model } & \multicolumn{2}{c|}{ MNCEE data } \\
\hline Model & Stories & $\begin{array}{c}\text { \# of } \\
\text { units }\end{array}$ & $\begin{array}{c}\text { Year } \\
\text { Built }\end{array}$ & $\begin{array}{c}\text { Single unit Q50, } \\
\text { L/s (cfm) }\end{array}$ & $\begin{array}{c}\text { Building } \\
\text { description }\end{array}$ & $\begin{array}{c}\text { Median Q50, } \\
\text { L/s (cfm) }\end{array}$ \\
\hline APT 67 & 1 & 16 & $1940-69$ & $696(1475)$ & 196412 plex & $433(917)$ \\
\hline APT 41 & 1 & 6 & $1970-89$ & $867(1836)$ & 1970 pplex & $476(1008)$ \\
\hline APT 4 & 2 & 4 & $<1940$ & $869(1842)$ & 1935 duplex & $1118(2368)$ \\
\hline APT 60 & 4 & 6 & $1990+$ & $225(476)$ & 20014 story & $546(1156)$ \\
\hline APT 36 & 10 & 200 & $1970-89$ & $746(1581)$ & 1999138 unit & $314(665)$ \\
\hline APT 36 & 10 & 200 & $1970-89$ & $746(1581)$ & 198211 story & $214(454)$ \\
\hline
\end{tabular}

Table A2 Comparison of Apartment Leakage Data

\section{REFERENCES}

Sherman M and Dickeroff D. 1998. Air-tightness of U.S. Dwellings. ASHRAE Transactions. 104(2):1359-1367.

Chan W, Price P, Sohn M, and Gadgil A. 2003. Analysis of U.S. Residential Air Leakage Database. Report Number 53367, Lawrence Berkeley National Laboratory.

Chan, WR, Nazaroff WW, Price PN, Sohn MD and Gadgil AJ. 2005. Analyzing a database of residential air leakage in the United States. Atmospheric Environment, 39: 3445-3455.

CEE 2004. Reduction of Environmental Tobacco Smoke Transfer in Minnesota Multifamily Buildings Using Air Sealing and Ventilation Treatments. Report CEE/TR04-1-MF. Center for Energy and Environment. Minneapolis, MN. 


\section{APPENDIX B: House Characteristics}

This appendix contains four tables that define the 209 dwellings, with one table for each housing type: detached (B1), attached (B2), manufactured home (B3) and apartment (B4). The dwelling definitions in the table are in terms of the variables discussed in the body of the report. Other information related to the dwelling models, including the number of homes in the RECS survey represented by the model and the floor plan code for that dwelling, are also listed in the tables. 
Table B1. Modeling details - Detached Homes (83 total)

Key to variables at end of table

\begin{tabular}{|c|c|c|c|c|c|c|c|c|c|c|c|c|c|}
\hline \multirow[b]{2}{*}{$\begin{array}{c}\text { House } \\
\text { Number }\end{array}$} & \multirow[b]{2}{*}{$\begin{array}{c}\text { \# of } \\
\text { Floors }\end{array}$} & \multicolumn{5}{|c|}{ House Variable } & \multicolumn{2}{|c|}{ RECS Data } & \multicolumn{4}{|c|}{ Mean \# of Rooms } & \multirow[b]{2}{*}{$\begin{array}{l}\text { Floor } \\
\text { plan }\end{array}$} \\
\hline & & $\begin{array}{l}\text { Floor } \\
\text { area }\end{array}$ & $\begin{array}{l}\text { Year } \\
\text { Built }\end{array}$ & $\begin{array}{l}\text { Found } \\
\text {-ation }\end{array}$ & Garage & $\begin{array}{c}\text { Forced } \\
\text {-air }\end{array}$ & $\begin{array}{c}\text { \# of } \\
\text { Homes }\end{array}$ & Weight & $\begin{array}{l}\text { Bed- } \\
\text { rooms }\end{array}$ & $\begin{array}{c}\text { Full } \\
\text { baths }\end{array}$ & $\begin{array}{c}\text { Half } \\
\text { baths }\end{array}$ & Other & \\
\hline DH-1 & 1 & 2 & 3 & 1 & 2 & 2 & 109 & 2185179 & 3 & 2 & 0 & 3 & DH-B(1) \\
\hline DH-2 & 1 & 1 & 2 & 3 & 2 & 2 & 111 & 1930684 & 3 & 1 & 0 & 3 & DH-A(8) \\
\hline DH-3 & 1 & 1 & 2 & 2 & 1 & 1 & 114 & 1730307 & 2 & 1 & 0 & 2 & DH-A(1) \\
\hline DH-4 & 1 & 1 & 2 & 2 & 2 & 2 & 83 & 1491818 & 3 & 1 & 0 & 3 & $\mathrm{DH}-\mathrm{A}(7)$ \\
\hline DH-5 & 1 & 1 & 3 & 1 & 2 & 2 & 65 & 1306058 & 3 & 2 & 0 & 3 & $\mathrm{DH}-\mathrm{A}(2)$ \\
\hline DH-6 & 2 & 1 & 1 & 3 & 2 & 2 & 66 & 1140420 & 3 & 1 & 0 & 3 & $\mathrm{DH}-\mathrm{D}(3)$ \\
\hline DH-7 & 1 & 2 & 2 & 3 & 2 & 2 & 61 & 1107980 & 3 & 2 & 0 & 4 & $\mathrm{DH}-\mathrm{B}(5)$ \\
\hline DH-8 & 1 & 1 & 2 & 1 & 2 & 2 & 56 & 1029268 & 3 & 2 & 0 & 3 & DH-A(2) \\
\hline DH-9 & 2 & 1 & 2 & 3 & 2 & 2 & 53 & 1022407 & 3 & 1 & 0 & 3 & DH-D(3) \\
\hline DH-10 & 2 & 2 & 3 & 3 & 2 & 2 & 55 & 1016922 & 4 & 2 & 1 & 4 & DH-E(8) \\
\hline DII-11 & 1 & 1 & 2 & 2 & 2 & 1 & 57 & 1016685 & 3 & 1 & 0 & 3 & $\mathrm{DH}-\mathrm{A}(7)$ \\
\hline DH-12 & 2 & 3 & 3 & 3 & 2 & 2 & 59 & 1013802 & 4 & 2 & 1 & 5 & DH-F(4) \\
\hline DH-13 & 1 & 2 & 2 & 2 & 2 & 2 & 56 & 997221 & 3 & 2 & 0 & 3 & DH-B(1) \\
\hline DH-14 & 2 & 2 & 1 & 3 & 2 & 2 & 55 & 970354 & 3 & 1 & 1 & 4 & DH-E(5) \\
\hline DH-15 & 2 & 3 & 4 & 3 & 2 & 2 & 36 & 947526 & 4 & 3 & 1 & 5 & DH-F(5) \\
\hline DH-16 & 1 & 1 & 2 & 2 & 1 & 2 & 56 & 838556 & 3 & 1 & 0 & 3 & DH-A(7) \\
\hline DH-17 & 2 & 2 & 2 & 3 & 2 & 2 & 43 & 803384 & 3 & 2 & 1 & 4 & DH-E(6) \\
\hline DH-18 & 2 & 1 & 1 & 3 & 1 & 2 & 45 & 742844 & 3 & 1 & 0 & 3 & DH-D(3) \\
\hline DH-19 & 1 & 1 & 3 & 3 & 2 & 2 & 40 & 727963 & 3 & 1 & 0 & 3 & DH-A(8) \\
\hline DH-20 & 2 & 2 & 1 & 3 & 2 & 1 & 39 & 720815 & 4 & 1 & 0 & 4 & $\mathrm{DH}-\mathrm{E}(7)$ \\
\hline DH-2l & 1 & 1 & 2 & 1 & 1 & 2 & 47 & 708504 & 3 & 1 & 0 & 3 & DH-A(7) \\
\hline DH-22 & 2 & 3 & 3 & 1 & 2 & 2 & 27 & 690163 & 4 & 3 & 1 & 5 & $\mathrm{DH}-\mathrm{F}(1)$ \\
\hline DH-23 & 2 & 1 & 1 & 3 & 2 & 1 & 44 & 684661 & 3 & 1 & 0 & 3 & DH-D(3) \\
\hline DH-24 & 2 & 2 & 3 & 1 & 2 & 2 & 31 & 645193 & 4 & 2 & 1 & 4 & DH-E(3) \\
\hline DH-25 & 1 & 1 & 2 & 3 & 2 & 1 & 45 & 642330 & 3 & 1 & 0 & 3 & DH-A(8) \\
\hline DH-26 & 1 & 1 & 2 & 1 & 1 & 1 & 39 & 635246 & 2 & 1 & 0 & 2 & DH-A(1) \\
\hline DH-27 & 1 & 1 & 2 & 3 & 1 & 2 & 38 & 601468 & 3 & 1 & 0 & 3 & DH-A(8) \\
\hline DH-28 & 2 & 3 & 4 & 1 & 2 & 2 & 19 & 580448 & 4 & 3 & 1 & 4 & $\mathrm{DH}-\mathrm{F}(2)$ \\
\hline DH-29 & 1 & 1 & 1 & 2 & 1 & 1 & 39 & 574063 & 2 & 1 & 0 & 3 & DH-A(3) \\
\hline
\end{tabular}




\begin{tabular}{|c|c|c|c|c|c|c|c|c|c|c|c|c|c|}
\hline \multirow[b]{2}{*}{$\begin{array}{c}\text { House } \\
\text { Number }\end{array}$} & \multirow[b]{2}{*}{$\begin{array}{c}\text { \# of } \\
\text { Floors }\end{array}$} & \multicolumn{5}{|c|}{ House Variable } & \multicolumn{2}{|c|}{ RECS Data } & \multicolumn{4}{|c|}{ Mean \# of Rooms } & \multirow[b]{2}{*}{$\begin{array}{l}\text { Floor } \\
\text { plan }\end{array}$} \\
\hline & & $\begin{array}{l}\text { Floor } \\
\text { area }\end{array}$ & $\begin{array}{l}\text { Year } \\
\text { Built }\end{array}$ & $\begin{array}{l}\text { Found } \\
\text {-ation }\end{array}$ & Garage & $\begin{array}{c}\text { Forced } \\
\text {-air } \\
\end{array}$ & $\begin{array}{c}\text { \# of } \\
\text { Homes }\end{array}$ & Weight & $\begin{array}{l}\text { Bed- } \\
\text { rooms }\end{array}$ & $\begin{array}{c}\text { Full } \\
\text { baths }\end{array}$ & $\begin{array}{c}\text { Half } \\
\text { baths }\end{array}$ & Other & \\
\hline DH-30 & 1 & 2 & 3 & 2 & 2 & 2 & 31 & 571692 & 3 & 2 & 0 & 3 & $\mathrm{DH}-\mathrm{B}(1)$ \\
\hline DH-31 & 1 & 1 & 3 & 2 & 2 & 2 & 32 & 565329 & 3 & 2 & 0 & 3 & $\mathrm{DH}-\mathrm{A}(2)$ \\
\hline DH-32 & 1 & 1 & 4 & 1 & 2 & 2 & 20 & 552255 & 3 & 2 & 0 & 2 & $\mathrm{DH}-\mathrm{A}(6)$ \\
\hline DH -33 & 1 & 3 & 3 & 1 & 2 & 2 & 27 & 549619 & 4 & 2 & 0 & 4 & DH-C(1) \\
\hline DH-34 & 1 & 1 & 3 & 1 & 1 & 2 & 31 & 524933 & 3 & 1 & 0 & 3 & $\mathrm{DH}-\mathrm{A}(7)$ \\
\hline DH-35 & 1 & 2 & 2 & 1 & 2 & 2 & 29 & 520116 & 3 & 2 & 0 & 3 & DH-B(1) \\
\hline DH -36 & 2 & 2 & 4 & 1 & 2 & 2 & 20 & 519749 & 4 & 2 & 1 & 4 & DH-E(3) \\
\hline DH $1-37$ & 1 & 2 & 3 & 3 & 2 & 2 & 27 & 511492 & 3 & 2 & 1 & 3 & DH-B(4) \\
\hline DH-38 & 1 & 1 & 3 & 2 & 1 & 2 & 30 & 497620 & 3 & 1 & 0 & 3 & DH-A(7) \\
\hline DH-39 & 1 & 2 & 2 & 2 & 1 & 2 & 30 & 469257 & 3 & 2 & 0 & 3 & DH-B(1) \\
\hline DH -40 & 2 & 2 & 3 & 2 & 2 & 2 & 22 & 447207 & 4 & 2 & 1 & 4 & DH-E(3) \\
\hline DH-41 & 2 & 2 & 1 & 3 & 1 & 2 & 32 & 446950 & 3 & 1 & 0 & 4 & DH-E(1) \\
\hline DH-42 & 1 & 1 & 3 & 2 & 1 & 1 & 27 & 442268 & 3 & 1 & 0 & 2 & DH-A(4) \\
\hline DH-43 & 2 & 2 & 2 & 3 & 2 & 1 & 26 & 410024 & 4 & 2 & 0 & 4 & DH-E(2) \\
\hline DH -44 & 1 & 1 & 1 & 3 & 2 & 2 & 26 & 409001 & 2 & 1 & 0 & 3 & DH-A(9) \\
\hline DH-45 & 2 & 2 & 3 & 4 & 2 & 1 & 30 & 398786 & 4 & 2 & 1 & 4 & DH-E(3) \\
\hline $\mathrm{DH}-46$ & 1 & 1 & 2 & 1 & 2 & 1 & 24 & 380772 & 2 & 1 & 0 & 2 & DH-A(1) \\
\hline DH-47 & 1 & 1 & 3 & 2 & 2 & 1 & 25 & 376507 & 3 & 1 & 0 & 3 & DH-A(7) \\
\hline DH-48 & 1 & 1 & 4 & 2 & 1 & 2 & 17 & 368757 & 3 & 2 & 0 & 3 & $\mathrm{DH}-\mathrm{A}(2)$ \\
\hline DH-49 & 1 & 1 & 2 & 3 & 1 & 1 & 26 & 361389 & 3 & 1 & 0 & 3 & DH-A(8) \\
\hline DH-50 & 2 & 1 & 1 & 3 & 1 & 1 & 23 & 351778 & 3 & 1 & 0 & 3 & $\mathrm{DH}-\mathrm{D}(3)$ \\
\hline DH-51 & 2 & 3 & 3 & 2 & 2 & 2 & 19 & 348213 & 4 & 2 & 1 & 4 & DH-F(3) \\
\hline DH-52 & 2 & 3 & 1 & 4 & 2 & 2 & 22 & 347787 & 4 & 2 & 1 & 4 & $\mathrm{DH}-\mathrm{F}(3)$ \\
\hline DH-53 & 1 & 2 & 3 & 1 & 1 & 2 & 18 & 327779 & 3 & 2 & 0 & 3 & $\mathrm{DH}-\mathrm{B}(1)$ \\
\hline DH-54 & 1 & 1 & 1 & 2 & 1 & 2 & 19 & 323291 & 2 & 1 & 0 & 3 & DH-A(3) \\
\hline DH-55 & 1 & 1 & 4 & 2 & 2 & 2 & 14 & 320900 & 3 & 2 & 0 & 2 & $\mathrm{DH}-\mathrm{A}(6)$ \\
\hline DH-56 & 2 & 1 & 2 & 3 & 1 & 2 & 21 & 314026 & 3 & 1 & 0 & 3 & DH-D(3) \\
\hline DH-57 & 1 & 2 & 2 & 2 & 2 & 1 & 18 & 309112 & 3 & 2 & 0 & 4 & DH-B(3) \\
\hline DH-58 & 2 & 2 & 4 & 3 & 2 & 2 & 17 & 299726 & 3 & 2 & 1 & 4 & $\mathrm{DH}-\mathrm{E}(6)$ \\
\hline DH-59 & 2 & 3 & 2 & 3 & 2 & 1 & 17 & 293015 & 4 & 2 & 1 & 5 & $\mathrm{DH}-\mathrm{F}(4)$ \\
\hline DH-60 & 1 & 1 & 3 & 4 & 2 & 1 & 18 & 285825 & 3 & 1 & 0 & 3 & $\mathrm{DH}-\mathrm{A}(7)$ \\
\hline DH-61 & 1 & 1 & 1 & 4 & 1 & 2 & 17 & 285549 & 2 & 1 & 0 & 2 & $\mathrm{DH}-\mathrm{A}(1)$ \\
\hline DH-62 & 2 & 3 & 1 & 3 & 2 & 1 & 18 & 283742 & 4 & 2 & 1 & 5 & $\mathrm{DH}-\mathrm{F}(4)$ \\
\hline
\end{tabular}




\begin{tabular}{|c|c|c|c|c|c|c|c|c|c|c|c|c|c|}
\hline \multirow[b]{2}{*}{$\begin{array}{c}\text { House } \\
\text { Number }\end{array}$} & \multirow[b]{2}{*}{$\begin{array}{l}\text { \# of } \\
\text { Floors }\end{array}$} & \multicolumn{5}{|c|}{ House Variable } & \multicolumn{2}{|c|}{ RECS Data } & \multicolumn{4}{|c|}{ Mean \# of Rooms } & \multirow[b]{2}{*}{$\begin{array}{l}\text { Floor } \\
\text { plan }\end{array}$} \\
\hline & & $\begin{array}{l}\text { Floor } \\
\text { area }\end{array}$ & $\begin{array}{l}\text { Year } \\
\text { Built }\end{array}$ & $\begin{array}{l}\text { Found } \\
\text {-ation }\end{array}$ & Garage & $\begin{array}{c}\text { Forced } \\
\text {-air }\end{array}$ & $\begin{array}{c}\text { \# of } \\
\text { Homes }\end{array}$ & Weight & $\begin{array}{c}\text { Bed- } \\
\text { rooms }\end{array}$ & $\begin{array}{c}\text { Full } \\
\text { baths }\end{array}$ & $\begin{array}{c}\text { Half } \\
\text { baths }\end{array}$ & Other & \\
\hline DH-63 & 2 & 1 & 2 & 4 & 2 & 1 & 23 & 282152 & 3 & 1 & 1 & 3 & DH-D(4) \\
\hline DH-64 & 1 & 2 & 4 & 1 & 2 & 2 & 13 & 276193 & 3 & 2 & 0 & 3 & DH-B(1) \\
\hline DH-65 & 1 & 1 & 1 & 4 & 1 & 1 & 20 & 273431 & 2 & 1 & 0 & 3 & $\mathrm{DH}-\mathrm{A}(3)$ \\
\hline DH-66 & 1 & 2 & 2 & 1 & 2 & 1 & 17 & 273259 & 3 & 1 & 0 & 3 & $\mathrm{DH}-\mathrm{B}(2)$ \\
\hline DH-67 & 1 & 1 & 1 & 2 & 2 & 2 & 13 & 270968 & 3 & 1 & 0 & 3 & DH-A(7) \\
\hline DH-68 & 2 & 1 & 2 & 3 & 1 & 1 & 16 & 269052 & 3 & 1 & 0 & 3 & $\mathrm{DH}-\mathrm{D}(3)$ \\
\hline DH-69 & 2 & 3 & 3 & 4 & 2 & 1 & 16 & 265490 & 4 & 2 & 1 & 4 & $\mathrm{DH}-\mathrm{F}(3)$ \\
\hline DH-70 & 1 & 1 & 3 & 1 & 1 & 1 & 16 & 263674 & 2 & 1 & 0 & 2 & DH-A(1) \\
\hline DH-71 & 2 & 1 & 3 & 1 & 2 & 2 & 15 & 263107 & 3 & 2 & 1 & 3 & DH-D(1) \\
\hline DH-72 & 1 & 2 & 1 & 4 & 2 & 2 & 13 & 250826 & 3 & 2 & 0 & 4 & $\mathrm{DH}-\mathrm{B}(3)$ \\
\hline DH-73 & 2 & 1 & 3 & 4 & 2 & 2 & 13 & 244715 & 3 & 2 & 0 & 4 & $\mathrm{DH}-\mathrm{D}(2)$ \\
\hline DH-74 & 1 & 3 & 3 & 4 & 2 & 2 & 13 & 237998 & 3 & 2 & 1 & 5 & $\mathrm{DH}-\mathrm{C}(2)$ \\
\hline DH-75 & 3 & 2 & 3 & 1 & 2 & 2 & 11 & 237637 & 4 & 2 & 1 & 3 & DH-G(1) \\
\hline DH-76 & 1 & 1 & 4 & 4 & 2 & 2 & 11 & 235564 & 3 & 2 & 1 & 3 & DH-A(5) \\
\hline DH-77 & 3 & 2 & 3 & 4 & 2 & 2 & 12 & 235357 & 3 & 2 & 1 & 4 & $\mathrm{DH}-\mathrm{G}(2)$ \\
\hline DH-78 & 1 & 1 & 3 & 1 & 2 & 1 & 12 & 234540 & 3 & 1 & 0 & 3 & DH-A(7) \\
\hline DH-79 & 1 & 2 & 3 & 2 & 1 & 2 & 14 & 234475 & 3 & 2 & 0 & 3 & DH-B(1) \\
\hline DH-80 & 1 & 2 & 2 & 4 & 1 & 2 & 12 & 222802 & 3 & 2 & 0 & 4 & DH-B(3) \\
\hline DH-81 & 2 & 2 & 1 & 4 & 1 & 1 & 13 & 206578 & 3 & 2 & 0 & 4 & DH-E(4) \\
\hline $\mathrm{DH}-82$ & 1 & 2 & 2 & 4 & 2 & 1 & 13 & 205183 & 3 & 2 & 0 & 3 & DH-B(1) \\
\hline DH-83 & 1 & 1 & 3 & 3 & 1 & 2 & 13 & 204007 & 3 & 1 & 0 & 3 & $\mathrm{DH}-\mathrm{A}(8)$ \\
\hline
\end{tabular}

\section{Key for Table B1:}

\# of floors: 1 = one story; 2 = two story

Floor area: $1=$ less than $148.5 \mathrm{~m}^{2}\left(1,599 \mathrm{ft}^{2}\right) ; 2=148.6 \mathrm{~m}^{2}$ to $222.9 \mathrm{~m}^{2}\left(1,600 \mathrm{ft}^{2}\right.$ to $\left.2,399 \mathrm{ft}^{2}\right) ; 3=223.0 \mathrm{~m}^{2}\left(2,400 \mathrm{ft}^{2}\right)$ or $\mathrm{more}^{2}$

Year Built: $1=$ before $1940 ; 2=1940-69 ; 3=1970-89 ; 4=1990$ and newer

Foundation: 1 = concrete slab; $2=$ crawl space; $3=$ finished basement, $4=$ unfinished basement

Garage: $1=$ none; 2 attached garage

Forced Air: 1 = other; 2 = central system present

RECS data/\# of Homes: number of each home in the RECS survey

RECS data/Weight: weighting factor of each home for all US housing 
TABLE B2. Modeling details - Attached Homes (53 total)

Key to variables at end of table

\begin{tabular}{|c|c|c|c|c|c|c|c|c|c|c|c|c|c|}
\hline \multirow[b]{2}{*}{$\begin{array}{l}\text { House } \\
\text { Number }\end{array}$} & \multirow[b]{2}{*}{$\begin{array}{l}\text { \# of } \\
\text { Floors }\end{array}$} & \multicolumn{5}{|c|}{ House Variable } & \multicolumn{2}{|c|}{ RECS Data } & \multicolumn{4}{|c|}{ Mean \# of Rooms } & \multirow[b]{2}{*}{ Floor plan } \\
\hline & & $\begin{array}{l}\text { Floor } \\
\text { area }\end{array}$ & $\begin{array}{l}\text { Year } \\
\text { Built }\end{array}$ & $\begin{array}{l}\text { Found } \\
\text {-ation } \\
\end{array}$ & Garage & $\begin{array}{c}\text { Forced } \\
\text {-air } \\
\end{array}$ & $\begin{array}{c}\text { \# of } \\
\text { Homes }\end{array}$ & Weight & $\begin{array}{c}\text { Bed- } \\
\text { rooms }\end{array}$ & $\begin{array}{c}\text { Full } \\
\text { baths }\end{array}$ & $\begin{array}{c}\text { Half } \\
\text { baths }\end{array}$ & Other & \\
\hline All-I & 2 & 1 & 1 & 3 & 1 & 2 & 35 & 578214 & 2 & 1 & 0 & 3 & $\mathrm{AH}-\mathrm{C}(11)$ \\
\hline $\mathrm{AH}-2$ & 2 & 1 & 3 & 1 & 1 & 2 & 23 & 521245 & 2 & 2 & 1 & 3 & $\mathrm{AH}-\mathrm{C}(7)$ \\
\hline AH-3 & 1 & 1 & 3 & 1 & 1 & 2 & 17 & 459153 & 2 & 1 & 0 & 2 & $\mathrm{AH}-\mathrm{A}(2)$ \\
\hline All-4 & 1 & 1 & 3 & 1 & 2 & 2 & 13 & 321363 & 2 & 1 & 0 & 3 & $\mathrm{AH}-\mathrm{A}(3)$ \\
\hline All-5 & 2 & 1 & 2 & 3 & 1 & 1 & 14 & 316699 & 3 & 1 & 0 & 3 & $\mathrm{AH}-\mathrm{C}(15)$ \\
\hline AH-6 & 2 & 1 & 3 & 1 & 2 & 2 & 11 & 268691 & 2 & 2 & 1 & 3 & $\mathrm{AH}-\mathrm{C}(4)$ \\
\hline $\mathrm{AH}-7$ & 2 & 1 & 3 & 3 & 1 & 2 & 11 & 252037 & 3 & 2 & 1 & 3 & AH-C(16) \\
\hline $\mathrm{AH}-8$ & 1 & 1 & 2 & 1 & 1 & 1 & 16 & 233618 & 2 & 1 & 0 & 2 & $\mathrm{AH}-\mathrm{A}(2)$ \\
\hline AH-9 & 2 & 1 & 1 & 3 & 2 & 1 & 11 & 231469 & 3 & 2 & 1 & 4 & AH-C(17) \\
\hline $\mathrm{AH}-10$ & 2 & 1 & 1 & 3 & 1 & 1 & 15 & 220760 & 2 & 1 & 0 & 3 & AH-C(11) \\
\hline $\mathrm{AH}-11$ & 2 & 1 & 2 & 3 & 1 & 2 & 15 & 212814 & 3 & 1 & 0 & 3 & AH-C(15) \\
\hline $\mathrm{AH}-12$ & 1 & 1 & 4 & 1 & 2 & 2 & 5 & 173022 & 2 & 1 & 0 & 2 & $\mathrm{AH}-\mathrm{A}(1)$ \\
\hline AH -13 & 2 & 1 & 2 & 1 & 1 & 2 & 10 & 149352 & 2 & 2 & 1 & 2 & $\mathrm{AH}-\mathrm{C}(6)$ \\
\hline $\mathrm{AH}-14$ & 1 & 1 & 2 & 1 & 1 & 2 & 13 & 144284 & 2 & 1 & 0 & 2 & $\mathrm{AH}-\mathrm{A}(2)$ \\
\hline $\mathrm{AH}-15$ & 2 & 2 & 3 & 1 & 2 & 2 & 8 & 138425 & 3 & 1 & 0 & 3 & $\mathrm{AH}-\mathrm{D}(1)$ \\
\hline All-16 & 2 & 1 & 1 & 2 & 1 & 1 & 4 & 114912 & 2 & 1 & 0 & 2 & $\mathrm{AH}-\mathrm{C}(2)$ \\
\hline $\mathrm{AH}-17$ & 1 & 1 & 2 & 2 & 1 & 1 & 8 & 111713 & 1 & 1 & 0 & 2 & $\mathrm{AH}-\mathrm{A}(5)$ \\
\hline $\mathrm{AH}-18$ & 2 & 1 & 3 & 1 & 1 & 1 & 6 & 107467 & 2 & 1 & 0 & 2 & $\mathrm{AH}-\mathrm{C}(2)$ \\
\hline AH-19 & 2 & 1 & 2 & 1 & 2 & 2 & 6 & 106839 & 2 & 1 & 0 & 3 & $\mathrm{AH}-\mathrm{C}(3)$ \\
\hline $\mathrm{AH}-20$ & 2 & 1 & 1 & 4 & 2 & 2 & 7 & 100827 & 3 & 1 & 0 & 3 & $\mathrm{AH}-\mathrm{C}(12)$ \\
\hline AH-2I & 2 & 2 & 1 & 4 & 2 & 2 & 7 & 98706 & 3 & 1 & 0 & 3 & $\mathrm{AH}-\mathrm{D}(4)$ \\
\hline $\mathrm{AH}-22$ & 2 & 1 & 3 & 1 & 2 & 1 & 4 & 98643 & 2 & 2 & 1 & 2 & $\mathrm{AH}-\mathrm{C}(1)$ \\
\hline $\mathrm{AH}-23$ & 2 & 1 & 3 & 4 & 2 & 2 & 4 & 94223 & 3 & 2 & 1 & 3 & $\mathrm{AH}-\mathrm{C}(13)$ \\
\hline $\mathrm{AH}-24$ & 2 & 2 & 1 & 3 & 1 & 1 & 6 & 91427 & 3 & 1 & 0 & 3 & $\mathrm{AH}-\mathrm{D}(5)$ \\
\hline $\mathrm{AH}-25$ & 1 & 1 & 2 & 1 & 2 & 1 & 6 & 91173 & 2 & 1 & 0 & 2 & $\mathrm{AH}-\mathrm{A}(1)$ \\
\hline $\mathrm{AH}-26$ & 2 & 1 & 4 & 1 & 1 & 2 & 3 & 90212 & 3 & 2 & 1 & 2 & $\mathrm{AH}-\mathrm{C}(5)$ \\
\hline $\mathrm{AH}-27$ & 2 & 2 & 1 & 4 & 2 & 1 & 5 & 89646 & 3 & 1 & 0 & 5 & $\mathrm{AH}-\mathrm{D}(6)$ \\
\hline $\mathrm{AH}-28$ & 2 & 2 & 3 & 3 & 1 & 2 & 4 & 85872 & 3 & 2 & 1 & 3 & $\mathrm{AH}-\mathrm{D}(7)$ \\
\hline $\mathrm{AH}-29$ & 2 & 2 & 4 & 1 & 2 & 2 & 2 & 83853 & 2 & 1 & 0 & 3 & AH-D(2) \\
\hline AH-30 & 1 & 1 & 3 & 2 & 2 & 1 & 6 & 80968 & 2 & 1 & 0 & 2 & $\mathrm{AH}-\mathrm{A}(1)$ \\
\hline
\end{tabular}




\begin{tabular}{|c|c|c|c|c|c|c|c|c|c|c|c|c|c|}
\hline \multirow[b]{2}{*}{$\begin{array}{c}\text { House } \\
\text { Number }\end{array}$} & \multirow[b]{2}{*}{$\begin{array}{c}\text { \# of } \\
\text { Floors }\end{array}$} & \multicolumn{5}{|c|}{ House Variable } & \multicolumn{2}{|c|}{ RECS Data } & \multicolumn{4}{|c|}{ Mean \# of Rooms } & \multirow[b]{2}{*}{ Floor plan } \\
\hline & & $\begin{array}{l}\text { Floor } \\
\text { area }\end{array}$ & $\begin{array}{l}\text { Year } \\
\text { Built }\end{array}$ & $\begin{array}{l}\text { Found } \\
\text {-ation }\end{array}$ & Garage & $\begin{array}{c}\text { Forced } \\
\text {-air }\end{array}$ & $\begin{array}{c}\text { \# of } \\
\text { Homes }\end{array}$ & Weight & $\begin{array}{l}\text { Bed- } \\
\text { rooms }\end{array}$ & $\begin{array}{c}\text { Full } \\
\text { baths }\end{array}$ & $\begin{array}{c}\text { Half } \\
\text { baths }\end{array}$ & Other & \\
\hline $\mathrm{AH}-31$ & 1 & 1 & 2 & 3 & 1 & 2 & 4 & 80714 & 1 & 1 & 0 & 3 & $\mathrm{AH}-\mathrm{A}(7)$ \\
\hline $\mathrm{AH}-32$ & 1 & 1 & 2 & 4 & 2 & 2 & 5 & 80666 & 2 & 1 & 0 & 3 & $\mathrm{AH}-\mathrm{A}(4)$ \\
\hline $\mathrm{AH}-33$ & 1 & 1 & 1 & 3 & 1 & 2 & 4 & 79408 & 1 & 1 & 0 & 2 & $\mathrm{AH}-\mathrm{A}(6)$ \\
\hline AH-34 & 2 & 3 & 3 & 3 & 1 & 2 & 3 & 74965 & 4 & 3 & 2 & 4 & $\mathrm{AH}-\mathrm{E}(1)$ \\
\hline AH-35 & 2 & 1 & 2 & 1 & 1 & 1 & 5 & 73883 & 2 & 1 & 0 & 2 & $\mathrm{AH}-\mathrm{C}(2)$ \\
\hline $\mathrm{AH}-36$ & 1 & 1 & 2 & 1 & 2 & 2 & 4 & 71401 & 2 & 1 & 0 & 2 & $\mathrm{AH}-\mathrm{A}(1)$ \\
\hline AH-37 & 1 & 1 & 2 & 2 & 2 & 1 & 4 & 68914 & 2 & 1 & 0 & 2 & $\mathrm{AH}-\mathrm{A}(1)$ \\
\hline AH-38 & 1 & 1 & 1 & 4 & 2 & 1 & 4 & 67275 & 2 & 1 & 0 & 3 & $\mathrm{AH}-\mathrm{A}(4)$ \\
\hline AH-39 & 1 & 1 & 4 & 1 & 1 & 2 & 3 & 65157 & 2 & 1 & 0 & 2 & $\mathrm{AH}-\mathrm{A}(2)$ \\
\hline $\mathrm{AH}-40$ & 2 & 1 & 1 & 1 & 1 & 1 & 3 & 64445 & 1 & 1 & 0 & 1 & $\mathrm{AH}-\mathrm{C}(8)$ \\
\hline $\mathrm{AH}-4 \mathrm{l}$ & 2 & 2 & 2 & 3 & 1 & 2 & 3 & 63302 & 3 & 2 & 1 & 4 & $\mathrm{AH}-\mathrm{D}(8)$ \\
\hline AH-42 & 2 & 1 & 2 & 4 & 2 & 2 & 3 & 61601 & 2 & 1 & 0 & 3 & $\mathrm{AH}-\mathrm{C}(10)$ \\
\hline $\mathrm{AH}-43$ & 1 & 2 & 3 & 1 & 2 & 2 & 3 & 61587 & 3 & 1 & 0 & 3 & $\mathrm{AH}-\mathrm{B}(1)$ \\
\hline $\mathrm{AH}-44$ & 1 & 1 & 3 & 2 & 1 & 1 & 4 & 60364 & 1 & 1 & 0 & 2 & $\mathrm{AH}-\mathrm{A}(5)$ \\
\hline $\mathrm{AH}-45$ & 1 & 1 & 2 & 2 & 1 & 2 & 4 & 60074 & 2 & 1 & 0 & 2 & $\mathrm{AH}-\mathrm{A}(2)$ \\
\hline AH-46 & 2 & 1 & 2 & 2 & 1 & 2 & 2 & 59507 & 3 & 1 & 0 & 3 & $\mathrm{AH}-\mathrm{C}(9)$ \\
\hline $\mathrm{AH}-47$ & 1 & 1 & 3 & 4 & 2 & 2 & 3 & 59499 & 3 & 2 & 1 & 3 & AH-A(8) \\
\hline AH-48 & 2 & 1 & 3 & 2 & 1 & 2 & 5 & 54415 & 2 & 2 & 1 & 2 & $\mathrm{AH}-\mathrm{C}(6)$ \\
\hline $\mathrm{AH}-49$ & 1 & 1 & 1 & 2 & 2 & 1 & 3 & 54145 & 2 & 1 & 0 & 2 & $\mathrm{AH}-\mathrm{A}(1)$ \\
\hline AH-50 & 2 & 1 & 3 & 2 & 2 & 2 & 3 & 53687 & 2 & 2 & 1 & 3 & $\mathrm{AH}-\mathrm{C}(4)$ \\
\hline AH-51 & 2 & 1 & 3 & 3 & 1 & 1 & 4 & 52821 & 2 & 1 & 0 & 3 & $\mathrm{AH}-\mathrm{C}(11)$ \\
\hline AH-52 & 2 & 2 & 3 & 1 & 1 & 2 & 3 & 52106 & 3 & 2 & 1 & 4 & AH-D(3) \\
\hline $\mathrm{AH}-53$ & 1 & 1 & 4 & 2 & 1 & 2 & 3 & 51848 & 2 & 1 & 0 & 2 & $\mathrm{AH}-\mathrm{A}(2)$ \\
\hline
\end{tabular}

\section{Key for Table}

\# of floors: 1 = one story; 2 = two story

Floor area: $1=$ less than $148.5 \mathrm{~m}^{2}\left(1,599 \mathrm{ft}^{2}\right) ; 2=148.6 \mathrm{~m}^{2}$ to $222.9 \mathrm{~m}^{2}\left(1,600 \mathrm{ft}^{2}\right.$ to $\left.2,399 \mathrm{ft}^{2}\right) ; 3=223.0 \mathrm{~m}^{2}\left(2,400 \mathrm{ft}^{2}\right)$ or more Year Built: $1=$ before $1940 ; 2=1940-69 ; 3=1970-89 ; 4=1990$ and newer

Foundation: 1 = concrete slab; 2 = crawl space; $3=$ finished basement, $4=$ unfinished basement

Garage: $1=$ none; $2=$ attached garage

Forced Air: $1=$ other; 2 = central system present

RECS data/\# of Homes: number of each home in the RECS survey

RECS data/Weight: weighting factor of each home for all US housing 
TABLE B3. Modeling details - Manufactured Homes (4 total) Key to variables at end of table

\begin{tabular}{|c|c|c|c|c|c|c|c|c|c|c|}
\hline $\begin{array}{c}\text { Model } \\
\text { Number }\end{array}$ & $\begin{array}{l}\text { Floor } \\
\text { area }\end{array}$ & $\begin{array}{l}\text { Year } \\
\text { Built }\end{array}$ & $\begin{array}{c}\text { Forced } \\
\text {-air }\end{array}$ & $\begin{array}{c}\text { RECS: \# of } \\
\text { Homes }\end{array}$ & $\begin{array}{l}\text { RECS: } \\
\text { Weight }\end{array}$ & $\begin{array}{l}\text { Mean \# of } \\
\text { Bedrooms }\end{array}$ & $\begin{array}{l}\text { Mean \# } \\
\text { of Baths }\end{array}$ & $\begin{array}{l}\text { Mean \# of } \\
\text { Half baths }\end{array}$ & $\begin{array}{c}\text { Mean \# of } \\
\text { Other rooms }\end{array}$ & Floor plan \\
\hline $\mathrm{MH}-1$ & 1 & 3 & 2 & 171 & 2664598 & 2 & 1 & 0 & 2 & MH-B(1) \\
\hline $\mathrm{MH}-2$ & 1 & 4 & 2 & 56 & 883158 & 3 & 2 & 0 & 2 & $\mathrm{MH}-\mathrm{A}(1)$ \\
\hline $\mathrm{MH}-3$ & 1 & 3 & 1 & 39 & 595936 & 2 & 1 & 0 & 2 & MH-B(1) \\
\hline $\mathrm{MH}-4$ & 1 & 2 & 2 & 38 & 580199 & 2 & 1 & 0 & 2 & $\mathrm{MH}-\mathrm{B}(1)$ \\
\hline
\end{tabular}

\section{Key for Table B3:}

Floor area: $1=$ less than $148.5 \mathrm{~m}^{2}\left(1,599 \mathrm{ft}^{2}\right) ; 2=148.6 \mathrm{~m}^{2}\left(1,600 \mathrm{ft}^{2}\right)$ or more

Year Built: $1=$ before $1940 ; 2=1940-69 ; 3=1970-89 ; 4=1990$ and newer

Forced Air: 1 = other; 2 = central system present

RECS /\# of Homes: number of each home in the RECS survey

RECS /Weight: weighting factor of each home for all US housing 
TABLE B4. Modeling details - Apartments (69 total)

Key to variables at end of table

\begin{tabular}{|c|c|c|c|c|c|c|c|c|c|c|c|c|}
\hline & & \multicolumn{4}{|c|}{ House Variable } & \multicolumn{2}{|c|}{ RECS Data } & \multicolumn{4}{|c|}{ Mean \# of Rooms } & \multirow[b]{2}{*}{ Floor plan } \\
\hline $\begin{array}{c}\text { Model } \\
\text { Number }\end{array}$ & $\begin{array}{c}\text { \# of } \\
\text { Floors }\end{array}$ & $\begin{array}{c}\text { \# of } \\
\text { Units }\end{array}$ & $\begin{array}{l}\text { Floor } \\
\text { area }\end{array}$ & $\begin{array}{l}\text { Year } \\
\text { Built } \\
\end{array}$ & $\begin{array}{l}\text { Forced- } \\
\text { air }\end{array}$ & $\begin{array}{c}\text { \# of } \\
\text { Homes }\end{array}$ & Weight & $\begin{array}{l}\text { Bed- } \\
\text { rooms }\end{array}$ & $\begin{array}{c}\text { Full } \\
\text { baths }\end{array}$ & $\begin{array}{c}\text { Half } \\
\text { baths }\end{array}$ & Other & \\
\hline APT-1 & 2 & 3 & 1 & 3 & 2 & 42 & 664721 & 1 & 1 & 0 & 2 & APT-2A(7) \\
\hline APT-2 & 3 & 3 & 1 & 3 & 2 & 21 & 511570 & 2 & 1 & 0 & 2 & APT-3A(7) \\
\hline APT-3 & 4 & 5 & 1 & 3 & 1 & 37 & 489530 & 1 & 1 & 0 & 2 & APT-4B(1) \\
\hline APT-4 & 2 & 1 & 1 & 1 & 1 & 33 & 479427 & 1 & 1 & 0 & 2 & APT-2A(1) \\
\hline APT-5 & 2 & 1 & 1 & 2 & 1 & 27 & 459130 & 1 & 1 & 0 & 2 & APT-2A(1) \\
\hline APT-6 & 2 & 2 & 1 & 3 & 2 & 25 & 441017 & 1 & 1 & 0 & 2 & APT-2A(4) \\
\hline APT-7 & 2 & 1 & 1 & 2 & 2 & 19 & 389364 & 2 & 1 & 0 & 2 & APT-2A(2) \\
\hline APT-8 & 2 & 2 & 2 & 3 & 2 & 22 & 388484 & 2 & 2 & 0 & 2 & APT-2B(3) \\
\hline APT-9 & 2 & 1 & 1 & 3 & 2 & 19 & 344153 & 2 & 1 & 0 & 2 & $\mathrm{APT}-2 \mathrm{~A}(2)$ \\
\hline APT -10 & 2 & 3 & 1 & 3 & 1 & 17 & 309964 & 1 & 1 & 0 & 2 & APT-2A(7) \\
\hline APT-11 & 2 & 2 & 1 & 2 & 2 & 14 & 285231 & 2 & 1 & 0 & 2 & $\mathrm{APT}-2 \mathrm{~A}(5)$ \\
\hline APT-12 & 3 & 5 & 1 & 3 & 1 & 14 & 267078 & 1 & 1 & 0 & 2 & APT-3A(10) \\
\hline APT -13 & 4 & 5 & 1 & 1 & 1 & 13 & 254804 & 1 & 1 & 0 & 2 & APT-4B(1) \\
\hline APT-14 & 2 & 1 & 2 & 3 & 2 & 13 & 246843 & 2 & 1 & 0 & 3 & APT-2B(1) \\
\hline APT-15 & 2 & 2 & 1 & 3 & 1 & 17 & 245944 & 2 & 1 & 0 & 2 & APT-2A(5) \\
\hline APT-16 & 1 & 1 & 1 & 2 & 1 & 19 & 244120 & 2 & 1 & 0 & 2 & APT-1A(2) \\
\hline APT-17 & 3 & 4 & 1 & 2 & 1 & 16 & 223585 & 1 & 1 & 0 & 2 & APT-3A(9) \\
\hline APT-18 & 3 & 1 & 1 & 1 & 1 & 19 & 213875 & 2 & 1 & 0 & 2 & APT-3A(1) \\
\hline APT-19 & 3 & 3 & 1 & 3 & 1 & 14 & 213350 & 2 & 1 & 0 & 2 & APT-3A(7) \\
\hline APT-20 & 2 & 3 & 1 & 2 & 2 & 16 & 209785 & 1 & 1 & 0 & 2 & APT-2A(7) \\
\hline APT-21 & 2 & 3 & 2 & 3 & 2 & 11 & 205202 & 2 & 1 & 0 & 2 & APT-2B(6) \\
\hline APT-22 & 2 & 1 & 1 & 3 & 1 & 14 & 204024 & 2 & 1 & 0 & 2 & APT-2A(2) \\
\hline APT-23 & 3 & 4 & 1 & 3 & 2 & 6 & 199294 & 1 & 1 & 0 & 2 & APT-3A(9) \\
\hline APT-24 & 5 & 5 & 1 & 2 & 1 & 14 & 174581 & 1 & 1 & 0 & 2 & APT-5A(1) \\
\hline APT-25 & 2 & 3 & 1 & 2 & 1 & 10 & 173628 & 1 & 1 & 0 & 2 & APT-2A(7) \\
\hline APT-26 & 3 & 3 & 1 & 2 & 1 & 11 & 170140 & 1 & 1 & 0 & 2 & APT-3A(8) \\
\hline APT-27 & 3 & 4 & 1 & 2 & 2 & 6 & 169678 & 1 & 1 & 0 & 2 & APT-3A(9) \\
\hline APT-28 & 2 & 1 & 2 & 1 & 1 & 10 & 164628 & 3 & 1 & 0 & 3 & APT-2B(2) \\
\hline APT-29 & 3 & 2 & 1 & 2 & 1 & 14 & 160066 & 2 & 1 & 0 & 2 & APT-3A(3) \\
\hline APT -30 & 4 & 5 & 1 & 2 & 1 & 12 & 156932 & 1 & 1 & 0 & 2 & APT-4B(1) \\
\hline
\end{tabular}




\begin{tabular}{|c|c|c|c|c|c|c|c|c|c|c|c|c|}
\hline & & \multicolumn{4}{|c|}{ House Variable } & \multicolumn{2}{|c|}{ RECS Data } & \multicolumn{4}{|c|}{ Mean \# of Rooms } & \multirow[b]{2}{*}{ Floor plan } \\
\hline $\begin{array}{c}\text { Model } \\
\text { Number }\end{array}$ & $\begin{array}{c}\text { \# of } \\
\text { Floors } \\
\end{array}$ & $\begin{array}{c}\text { \# of } \\
\text { Units } \\
\end{array}$ & $\begin{array}{c}\text { Floor } \\
\text { area }\end{array}$ & $\begin{array}{l}\text { Year } \\
\text { Built }\end{array}$ & $\begin{array}{c}\text { Forced- } \\
\text { air }\end{array}$ & $\begin{array}{c}\text { \# of } \\
\text { Homes }\end{array}$ & Weight & $\begin{array}{c}\text { Bed- } \\
\text { rooms }\end{array}$ & $\begin{array}{c}\text { Full } \\
\text { baths }\end{array}$ & $\begin{array}{r}\text { Half } \\
\text { baths }\end{array}$ & Other & \\
\hline APT-31 & 2 & 2 & 2 & 2 & 1 & 10 & 155497 & 2 & 1 & 0 & 2 & APT-2B(4) \\
\hline APT-32 & 2 & 1 & 1 & $T$ & 2 & 9 & 155420 & 1 & 1 & 0 & 3 & APT-2A(3) \\
\hline APT-33 & 2 & 5 & 1 & 3 & 2 & 8 & 135934 & 1 & 1 & 0 & 2 & APT-2A(10) \\
\hline APT-34 & 3 & 4 & 1 & 1 & 1 & 8 & 132732 & 1 & 1 & 0 & 2 & APT-3A(9) \\
\hline APT-35 & 2 & 2 & 2 & 4 & 2 & 2 & 129848 & 2 & 1 & 1 & 2 & APT-2B(5) \\
\hline APT-36 & 4 & 5 & 1 & 3 & 2 & 11 & 129466 & 0 & 1 & 0 & 1 & APT-4B(2) \\
\hline APT -37 & 3 & 5 & 1 & 2 & 1 & 5 & 127308 & 1 & 1 & 0 & 2 & APT-3A(10) \\
\hline APT-38 & 2 & 4 & 1 & 3 & 2 & 10 & 121922 & 1 & 1 & 0 & 2 & APT-2A(8) \\
\hline APT-39 & 3 & 4 & 1 & 3 & 1 & 9 & 120021 & 1 & 1 & 0 & 2 & APT-3A(9) \\
\hline APT -40 & 2 & 2 & 1 & 2 & 1 & 11 & 119872 & 2 & 1 & 0 & 2 & APT-2A(5) \\
\hline APT-41 & 1 & 2 & 2 & 3 & 2 & 6 & 116485 & 2 & 1 & 0 & 3 & APT-1B(1) \\
\hline APT-42 & 3 & 2 & 1 & 1 & 1 & 6 & 113702 & 2 & 1 & 0 & 3 & APT-3A(4) \\
\hline APT-43 & 3 & 3 & 2 & 3 & 1 & 7 & 113334 & 2 & 1 & 0 & 2 & APT-3B(2) \\
\hline APT-44 & 3 & 3 & 1 & 1 & 1 & 7 & 111144 & 1 & 1 & 0 & 2 & $\mathrm{APT}-3 \mathrm{~A}(8)$ \\
\hline APT-45 & 3 & 5 & 2 & 2 & 1 & 5 & 109309 & 2 & 1 & 0 & 2 & APT-3B(5) \\
\hline APT-46 & 3 & 1 & 1 & 2 & 1 & 7 & 106822 & 2 & 1 & 0 & 3 & APT-3A(2) \\
\hline APT-47 & 1 & 1 & 1 & 3 & 2 & 7 & 106196 & 1 & 1 & 0 & 2 & APT-1A(1) \\
\hline APT-48 & 3 & 5 & 1 & 1 & 1 & 8 & 105582 & 1 & 1 & 0 & 2 & APT-3A(10) \\
\hline APT-49 & 3 & 5 & 1 & 2 & 2 & 6 & 104279 & 1 & 1 & 0 & 2 & APT-3A(10) \\
\hline APT-50 & 3 & 4 & 2 & 3 & 2 & 2 & 100899 & 2 & 2 & 0 & 3 & $\mathrm{APT}-3 \mathrm{~B}(4)$ \\
\hline APT-5I & 3 & 1 & 2 & 1 & 1 & 8 & 97205 & 3 & 1 & 0 & 3 & APT-3B(1) \\
\hline APT-52 & 4 & 5 & 1 & 2 & 2 & 3 & 96106 & 2 & 1 & 0 & 2 & APT-4B(3) \\
\hline APT-53 & 2 & 5 & 1 & 2 & 2 & 4 & 91792 & 2 & 1 & 1 & 2 & APT-2A(11) \\
\hline APT-54 & 2 & $\overline{4}$ & 1 & 3 & 1 & 6 & 87866 & 2 & 1 & 0 & 2 & APT-2A(9) \\
\hline APT -55 & 2 & 2 & 2 & 2 & 2 & 4 & 86579 & 2 & 2 & 0 & 2 & APT-2B(3) \\
\hline APT-56 & 2 & 4 & 1 & 2 & 1 & 5 & 85183 & 1 & 1 & 0 & 2 & APT-2A(8) \\
\hline APT-57 & 1 & 2 & 1 & 3 & 2 & 5 & 83830 & 2 & 1 & 0 & 2 & APT-1A(3) \\
\hline APT-58 & 2 & 3 & 2 & 2 & 1 & 6 & 80915 & 2 & 1 & 0 & 2 & APT-2B(6) \\
\hline APT-59 & 2 & 2 & 1 & 4 & 2 & 3 & 74528 & 2 & 2 & 0 & 3 & APT-2A(6) \\
\hline APT -60 & 3 & 2 & 1 & 4 & 2 & 1 & 74274 & 2 & 1 & 1 & 2 & APT-3A(5) \\
\hline APT-61 & 3 & 2 & 1 & 2 & 2 & 3 & 73726 & 2 & 1 & 0 & 2 & APT-3A(3) \\
\hline APT-62 & 2 & 2 & 1 & 4 & 1 & 3 & 73558 & 1 & 1 & 0 & 2 & APT-2A(4) \\
\hline APT- 63 & 3 & 5 & 2 & 2 & 2 & 3 & 71765 & 2 & 2 & 0 & 2 & APT-3B $(6)$ \\
\hline
\end{tabular}




\begin{tabular}{|c|c|c|c|c|c|c|c|c|c|c|c|c|}
\hline \multirow[b]{2}{*}{$\begin{array}{c}\text { Model } \\
\text { Number }\end{array}$} & \multirow[b]{2}{*}{$\begin{array}{c}\text { \# of } \\
\text { Floors }\end{array}$} & \multicolumn{4}{|c|}{ House Variable } & \multicolumn{2}{|c|}{ RECS Data } & \multicolumn{4}{|c|}{ Mean \# of Rooms } & \multirow[b]{2}{*}{ Floor plan } \\
\hline & & $\begin{array}{c}\text { \# of } \\
\text { Units }\end{array}$ & $\begin{array}{l}\text { Floor } \\
\text { area }\end{array}$ & $\begin{array}{l}\text { Year } \\
\text { Built }\end{array}$ & $\begin{array}{c}\text { Forced- } \\
\text { air }\end{array}$ & $\begin{array}{c}\text { \# of } \\
\text { Homes }\end{array}$ & Weight & $\begin{array}{c}\text { Bed- } \\
\text { rooms }\end{array}$ & $\begin{array}{c}\text { Full } \\
\text { baths }\end{array}$ & $\begin{array}{c}\text { Half } \\
\text { baths }\end{array}$ & Other & \\
\hline APT-64 & 2 & 3 & 1 & 4 & 2 & 4 & 71208 & 1 & 1 & 0 & 2 & APT-2A(7) \\
\hline APT-65 & 3 & 5 & 1 & 3 & 2 & 3 & 70356 & 1 & 1 & 0 & 2 & APT-3A(10) \\
\hline APT- 66 & 3 & 3 & 2 & 1 & 2 & 2 & 70066 & 2 & 1 & 1 & 3 & $\mathrm{APT}-3 \mathrm{~B}(3)$ \\
\hline APT-67 & 1 & 3 & 1 & 2 & 1 & 3 & 69529 & 1 & 1 & 1 & 2 & APT-1A(4) \\
\hline APT-68 & 3 & 2 & 1 & 3 & 1 & 3 & 66016 & 2 & 2 & 0 & 2 & APT-3A(6) \\
\hline APT-69 & 4 & 2 & 1 & 4 & 2 & 1 & 64924 & 2 & 1 & 1 & 2 & APT-4A(1) \\
\hline
\end{tabular}

\section{Key for Table B4:}

\# of floors: $1=1$ story; $2=2$ story; $3=3$ to 5 stories (modeled as 4$) ; 4=6-15$ stories (modeled as 10$) ; 5=16+$ stories (modeled as 10 ) \# of units: $1=2$ to 4 (modeled as 4 ); $2=5$ to 9 (modeled as 6$) ; 3=10$ to 19 (modeled as 16 ); $4=20$ to 39 (modeled as 32 ); $5=40+$ units in building (modeled as 20 units per floor)

Floor area: $1=$ less than $92.8 \mathrm{~m}^{2}\left(999 \mathrm{ft}^{2}\right) ; 2=92.9 \mathrm{~m}^{2}\left(1,000 \mathrm{ft}^{2}\right)$ or more

Year Built: $1=$ before $1940 ; 2=1940-69 ; 3=1970-89 ; 4=1990$ and newer

Forced Air: $1=$ other; 2 = central system present

RECS data/\# of Homes: number of each home in the RECS survey

RECS data/Weight: weighting factor of each home for all US housing 